\title{
Mail-In Absentee Ballot Anomalies in North Carolina's 9th Congressional District
}

\author{
Michael C. Herron
}

\begin{abstract}
The aftermath of the 2018 midterm election in North Carolina was marred by allegations of absentee ballot fraud in the state's 9th Congressional District, most notably in Bladen County, one of eight counties in North Carolina that intersects this district. We show with a difference-in-difference design that Bladen County's election returns in 2018 are indeed highly anomalous: compared to congressional candidates in other North Carolina counties, the 9th District's Republican candidate for the United States House of Representatives had in Bladen County a mail-in absentee vote share inconsistent with his level of Election Day support. Bladen County's 2018 congressional election results are also anomalous when compared with North Carolina congressional elections of 2010, 2012, 2014, and 2016, and they are likewise anomalous when compared with recent congressional elections in Arkansas, Georgia, and Oklahoma, three states that tabulate election results in a way that facilitates comparisons with North Carolina. Beyond the 2018 midterm, congressional election returns in Bladen County exhibited anomalous mail-in absentee voting patterns in the 2018 Republican primary and in the 2016 general election. Finally, rates of requested and returned mail-in absentee ballots in the period surrounding the 2018 midterm were anomalous in both Bladen and neighboring Robeson counties. Our statistical results are consistent with investigative findings presented in February 2019 to the North Carolina State Board of Elections, which voted unanimously on February 21, 2019, to hold a new election in Congressional District 9.
\end{abstract}

Keywords: election administration, election fraud, absentee voting, election forensics

\section{INTRODUCTION}

$\mathbf{T}$ HE AFTERMATH OF THE 2018 MIDTERM ELECTION in North Carolina was marred by fraud alle-

Michael C. Herron is a professor of government at Dartmouth College in Hanover, New Hampshire. The first version of this article was released on the Internet on December 28, 2018. On February 6, 2019, at the request of counsel on behalf of congressional candidate Dan McCready, in the litigation "Investigation of Election Irregularities Affecting Counties Within the 9th Congressional District," then-pending before the North Carolina State Board of Elections, I provided a working draft of this paper as my expert analysis of the issues at bar. The State Board of Elections' report on its hearing cites this draft on pages 35-36. The author thanks Addison Dick and Jacqueline McInerney for research assistance and seminar participants from the Free University of Berlin, Humboldt University, the University of Pittsburgh, and the University of Salzburg, Jacob Bhalif Chalif, Katherine Clayton, Martha Kropf, Melissa Herman, Simon Herron, and three anonymous referees for comments on earlier drafts. gations in the state's 9th Congressional District. Investigators there voiced concerns that absentee ballots were tampered with in Bladen County, a southern county in North Carolina which intersects the 9th District. Bladen County is relatively small, containing only 23,295 registered voters as of the 2018 midterm; a neighboring county to the west, Robeson, with 77,306 registered voters, also figured in the fraud allegations that ensnared the 9th Congressional District. ${ }^{1}$

This district in 2018 featured a competitive race between Republican Mark Harris and Democrat

\footnotetext{
${ }^{1}$ Based on the 2013-2017 American Community Survey, Bladen County had a population of 34,130 and Robeson a population of 134,187. Registered voter counts are based on the file “voter_stats_20181106.zip," downloaded from <https://dl.ncsbe .gov/index.html?prefix =ENRS/2018_11_06/> (last accessed January 5, 2019).
} 
Dan McCready. Per initial results, Harris, who was the beneficiary of the alleged mail-in absentee ballot fraud, won his race with 139,246 votes to McCready's 138,341; Jeff Scott, a Libertarian candidate, received 5,130 votes. ${ }^{2}$ There was no incumbent in the 9th District contest in November 2018; Harris previously defeated the district's sitting member of Congress, Robert Pittenger, in a May 2018 primary.

The Harris-McCready margin was narrow, only 905 votes out of a total of 282,717 ballots cast. As there were 10,651 mail-in absentee votes cast in the Harris-McCready contest, the pro-Harris absentee ballot fraud alleged to have contaminated the race was conceivably pivotal to its outcome. ${ }^{3}$

Allegations of fraud in American elections are not new (Minnite 2010; Hasen 2018), and voter fraud featured prominently in the aftermath of the 2016 general election (Cottrell, Herron, and Westwood 2018). Although many Americans profess to believe otherwise (Ansolabehere and Persily 2008), there is no evidence that fraud is a widespread problem in American elections (e.g., Ahlquist, Mayer, and Jackman 2014). For example, see Goel et al. $(2017)^{4}$ for a discussion of the literature on voter fraud and a statistical analysis showing that the rate of double-voting in American elections is minuscule. Evidence notwithstanding, beliefs in voter fraud are associated with support for voter identification laws (Wilson and Brewer 2013) and with feelings of resentment against immigrants (Udani and Kimball 2018).

Regular and fair elections are fundamental to modern democracies (Katz 1997), and serious allegations of improprieties deserve formal investigations regardless of the lack of evidence that election fraud in the United States is widespread. Such investigations can take many forms, ranging from detailed studies of individuals who may be perpetrators to statistical analyses of vote patterns. Here we offer an analysis of the latter type and in so doing propose a general statistical approach that is applicable beyond the Harris-McCready race in North Carolina's 9th Congressional District. Key to the analysis is a difference-in-difference model, whose intuition is as follows.

The 9th Congressional District touches eight counties in North Carolina: Anson, Bladen, Cumberland, Mecklenburg, Richmond, Robeson, Scotland, and Union. Bladen County itself is split between two congressional districts, the 7 th and 9th. If mail-in absentee ballot fraud in Bladen County in 2018 benefited Mark Harris, then Harris can be said to have received an excessive number of absentee votes in this county. The "correct" number of absentee votes that Harris would have received in the absence of any fraud is not observable. Thus, to assess the extent to which Harris's mail-in absentee ballot support rate in Bladen County was anomalous, we compare this rate to the rate at which David Rouzer, the Republican candidate in the 7th Congressional District in North Carolina, was preferred by voters who cast mail-in absentee ballots in Bladen County. Such a comparison is useful because North Carolina's 7th and 9th Congressional Districts both intersect Bladen County, and yet the alleged mail-in absentee ballot fraud in the county involves only the latter district.

To ensure that our comparison of Harris's and Rouzer's mail-in absentee ballot vote shares in Bladen County is not confounded by the two congressional candidates' overall levels of support in Bladen, our analysis of their mail-in absentee support is adjusted based on the extent to which these two candidates received votes on Election Day. The result of this exercise, as detailed below, is a difference-in-difference measure of the extent to which Mark Harris was supported by mail-in absentee voters in Bladen County compared to the rate at which Rouzer was similarly supported.

To foreshadow our results, our difference-indifference analysis shows that Mark Harris received an anomalously large number of mail-in absentee votes in Bladen County compared to his Election

\footnotetext{
${ }^{2}$ Election results on the website of the North Carolina State Board of Elections are available at <https://er.ncsbe.gov/ ?election_dt=11/06/2018\&county_id=0\&office=FED\&contest= 1183> (last accessed December 20, 2018).

${ }^{3}$ In this paragraph, 10,651 refers to the number of valid mail-in absentee votes cast in the 9th Congressional District in the 2018 midterm election in North Carolina. Any eligible voter residing in this district who turned out to vote in the 2018 midterm could have abstained from the congressional contest, yielding what is called an undervote in the race. Or, such a voter could have voted for more than one 9th District congressional candidate, yielding what is called an overvote. Neither undervotes nor overvotes constitute valid votes, and they do not contribute to the aforementioned count of 10,651.

${ }^{4}$ Goel, Sharad, Marc Meredith, Michael Morse, David Rothschild, and Houshmand Shirani-Mehr. 2017. "One Person, One Vote: Estimating the Prevalence of Double Voting in U.S. Presidential Elections." Working paper, available at <https://www.dropbox .com/s/bbzgpeolrh1s7dy/OnePersonOneVote.pdf $>$.
} 
Day support. Moreover, when we look across North Carolina at all 2018 congressional candidates who competed in counties that, like Bladen, are split between congressional districts, the 9th Congressional District race in Bladen County is associated with the largest mail-in absentee vote share advantage for a Republican congressional candidate in the entire state. Mark Harris's 2018 mail-in absentee vote share advantage in Bladen County is also the greatest among North Carolina congressional candidates across the midterm and general elections of 2010, 2012, 2014, and 2016. Bladen County's mail-in absentee vote share for 2016 District 9 Republican congressional candidate Robert Pittenger was also anomalous compared to Pittenger's Election Day support that year-albeit not as extensively as Mark Harris's corresponding mail-in absentee rate in 2018.

We also use our difference-in-difference model to compare mail-in absentee and Election Day support rates for North Carolina congressional candidates to corresponding support rates for congressional candidates in Arkansas, Georgia, and Oklahoma, three states whose election returns tabulating practices facilitate comparisons with North Carolina. Across recent elections in all four states in our purview, Mark Harris's 2018 mail-in absentee support rate in the 9th Congressional District in Bladen County is the most anomalous of all Republican candidates.

Finally, and as an additional exercise aimed at understanding the nature of absentee ballot abnormalities in the 2018 midterm election in North Carolina, we analyze mail-in absentee ballot request and return rates in this state in the period surrounding November 2018. We show that Robeson County, which borders Bladen County to the east, had an anomalous mail-in absentee request rate in this election in conjunction with a very low return rate. Bladen County and other counties in the 9th Congressional District had anomalously high request rates as well, rates that were among the greatest across North Carolina.

Our results are consistent with the allegations and subsequent investigations of mail-in absentee ballot fraud that were leveled in North Carolina's 9th Congressional District following the November 2018 midterm election. Insofar as concerns about mailin absentee ballot integrity were raised in recent North Carolina primary elections as well, we use our difference-in-difference approach to analyze election returns from the 2016 and 2018 North Carolina Democratic and Republican primaries. Among Republican primary candidates and in a way consistent with the 2018 midterm election, the mail-in absentee vote share for Mark Harris was anomalous compared to his Election Day vote share.

In short, our findings highlight the anomalous nature of North Carolina's 9th Congressional District in 2018, and in fact the North Carolina State Board of Elections voted unanimously on February 21,2019 , to order a new election in this district. ${ }^{5}$ Beyond North Carolina, our conclusions contribute to academic literature on election abnormalities in the United States and to statistical literature on election fraud in particular. We return to this point in the last section of the study, but for the moment it suffices to note that the sort of absentee ballot fraud that appears to have taken place in North Carolina in 2018 differs from the types of fraud-ineligible voting, double-voting, voter impersonationsomewhat regularly bandied about in public discourse in the United States.

Insofar as the motivation for this article was an allegation of election fraud, it is important to understand at the outset how a statistical analysis can contribute to the study of a potential fraud and how it cannot. In general, the nature of observational statistical analyses of vote returns, like the one here, is such that these analyses themselves cannot render conclusive verdicts on the presence of fraud, which ultimately is a legal matter that depends on the nature of election laws in a jurisdiction of interest. Rather, a statistical analysis can highlight an anomalous pattern in vote returns, one that could be notable in light of an allegation of impropriety.

None of our results thus speak to precise details about the roles that any individual personally had in North Carolina's 9th Congressional District during the run-up to the 2018 midterm election. Similarly, our results do not engage the nature of North Carolina election laws and the restrictions that

\footnotetext{
${ }^{5}$ The report of the State Board, dated March 13, 2019, is available at <https://dl.ncsbe.gov/State_Board_Meeting_Docs/ Congressional_District_9_Portal/Order_03132019.pdf $>$ (last accessed April 18, 2019). Also see Alan Blinder, "New Election Ordered in North Carolina Race at Center of Fraud Inquiry," New York Times, February 21, 2019, available at <https:// www.nytimes.com/2019/02/21/us/mark-harris-nc-voter-fraud .html> (last accessed February 22, 2019).
} 
these laws impose on candidates and voters. Finally, the results reported here do not identify what Mark Harris, the beneficiary of the ostensible mail-in absentee ballot fraud perpetrated in his district, knew prior to the 2018 midterm about potential absentee ballot anomalies. This issue was engaged at the aforementioned February 2019 hearing, at which evidence was presented that Mark Harris's son had warned his father about hiring the operative who, it appears as of this article's writing, organized the fraud that benefitted Mark Harris. ${ }^{6}$

In what follows, we situate our study in literature on election forensics. Thereafter we discuss the 2018 midterm election in North Carolina and describe a difference-in-difference statistic that compares the mail-in absentee and Election Day vote shares of two congressional candidates whose districts intersect the same county. After showing with this statistic that Bladen County had anomalous results among congressional candidates in 2018, we place this result in the context of recent elections in North Carolina. The next section incorporates election returns from several other states, and following this, we consider mail-in absentee and Election Day returns from two recent primary elections in North Carolina. Lastly, we present an analysis of mail-in absentee ballot return and request rates in the 2018 midterm election. The final section concludes.

\section{ELECTION FORENSICS AND ELECTION ANOMALIES}

The motivating question of this study is as follows: Is there evidence from the 2018 midterm and other elections in North Carolina that mailin absentee fraud allegations associated with the state's 9th Congressional District are credible? A statistical exercise that seeks to offer an answer to this question is an exercise in the field known as election forensics.

One type of election forensics analysis involves assessing whether a set of election outcomes is standard or anomalous. An anomalous election outcome could be one influenced by a confusing ballot format that led some voters to vote accidentally for an unintended candidate (Wand et al. 2001). An anomalous election outcome could also be a high undervote rate in an election, one induced by a ballot format that led to unintentional abstention (Frisina et al. 2008). Insofar as overvotes are invalid votes, a plethora of overvotes in an election would also constitute an anomalous election outcome (Mebane, Jr. 2004).

Some election forensics analyses are aimed specifically at fraud detection, and much of the literature in this area turns on the frequencies of digits in election returns. For example, Beber and Scacco (2012) study a set of elections held in Nigeria (2003), Senegal (2000 and 2007), and Sweden (2002) and conclude that there has been election manipulation in the two former countries. See Medzihorsky (2015) for a discussion of digit-based tests, Kalinin and Hicken (2017) ${ }^{7}$ for a recent application to Philippine elections, Kalinin and Mebane, Jr. $(2017)^{8}$ for a study of Russian elections, and Deckert, Myagkov, and Ordeshook (2011) for a critique of these tests (with Mebane, Jr. [2011] as a response). A related approach to digit-based tests is described by Rozenas (2017), who incorporates the presence of "coarse" numbers (e.g., 50, 60, or 70 percent) in election returns in tests for fraud.

The case of the 2018 midterm election in North Carolina is notable for the specificity of the fraud allegations associated with it. These allegations do not consist of assertions that there was widespread fraud in all congressional races in North Carolina in 2018 - nor that there was fraud in races beyond congressional contests. Rather, the allegations are precise about the jurisdiction of North Carolina that they may have affected, and this means that testing for their presence can rely on a focused analysis.

The statistical approach adopted in this study shares an important characteristic with digit-based fraud analyses. In particular, the difference-indifference analysis that follows is agnostic about the individual-level variables that scholars of American elections typically use to predict vote choices in congressional elections. Thus, the conclusions drawn here

\footnotetext{
${ }^{6}$ On Mark Harris and his son, see Brian Murphy, Jim Morrill, and Ely Portillo, "John Harris Warned His Father About Legal Red Flags Involving Bladen Operative," News \& Observer, February 20, 2019, available at https://www.news observer.com/news/politics-government/article226492265.html (last accessed February 20, 2019).

${ }^{7}$ Kalinin, Kirill and Allen Hicken. 2017. "Using Election Forensics to Detect Election Fraud in the Philippine Elections, 2016." Paper presented at the 2017 Annual Meeting of the American Political Science Association, available at <https:// papers.ssrn.com/sol3/papers.cfm?abstract_id=3070592>.

${ }^{8}$ Kalinin, Kirill and Walter R. Mebane, Jr. 2017. "Worst Election Ever in Russia?" Working paper, available at <https:// papers.ssrn.com/sol3/papers.cfm?abstract_id=2959824>.
} 
do not depend on a correct specification of how eligible voters in North Carolina developed preferences over sets of competing congressional candidates.

\section{THE 2018 MIDTERM ELECTION IN NORTH CAROLINA}

There are 13 congressional districts in North Carolina, and the 2018 midterm election in the state featured 12 races (District 3 had only one official candidate, a Republican). Of the 12 contested congressional races in 2018, three were won by Democrats and nine by Republicans. This latter group includes the 9th Congressional District, whose results have not been certified and will be superseded once a new election in the district is held. ${ }^{9}$

North Carolina voters have three methods of casting ballots: mail-in absentee, "one-stop" voting, and Election Day voting. One-stop voting is North Carolina's version of what in other states is often called early voting, and in North Carolina this form of voting is often referred to as "absentee onestop." In the interests of clarity, throughout this study we refer explicitly to "mail-in absentee" voting when we wish to emphasize the method of voting in which, in principle, a voting-eligible resident of North Carolina fills out a paper ballot in a location of his or her choosing, returning the ballot to a local elections office prior to 5:00 p.m. on Election Day. ${ }^{10}$

Our study of the 9th Congressional District focuses primarily on the contrast between mail-in absentee and Election Day results. However, we also present a limited set of results that contrast mailin absentee voting results with one-stop absentee results. As will be evident, our mail-in versus one-stop findings are qualitatively equivalent to our mail-in absentee versus Election Day findings, and to keep the presentation as straightforward as possible, we devote most of our attention to the latter.

\section{Allegations of fraud in Congressional District 9}

The fraud alleged to have been carried out in North Carolina's 9th Congressional District involves a plot coordinated by an individual named Leslie McCrae Dowless, Jr. According to press reporting, Dowless paid "people to collect mail-in absentee ballots, including unsealed ones," on behalf of Mark Harris's campaign. ${ }^{11}$ Per one report, Dowless "turned in nearly half of the requests for absentee ballots in [Bladen] county" in the period surrounding the 2018 midterm election. ${ }^{12}$ Dowless has also been connected with allegations of mailin absentee ballot fraud in 2014 and $2016 .{ }^{13}$ Moreover, in the weeks following the November 2018 election, questions relating to mail-in absentee ballot integrity were raised about Mark Harris's narrow victory-828 votes of 35,643 cast-over Robert Pittenger in North Carolina's 2018 Republican congressional primary. ${ }^{14}$

Other years notwithstanding, allegations of election fraud in North Carolina's 9th Congressional District are specific to mail-in absentee voting and imply that Republican congressional candidate Mark Harris received fraudulent mail-in absentee ballot support in the 2018 midterm election. Who precisely coordinated this fraud is not germane to the analysis here. What we care about is that the

${ }^{9}$ See note 4, supra, and Adam Levy, "North Carolina Elections Board Delays Certification of Congressional Election Results Again," CNN.com, December 3, 2018, available at <https:// www.cnn.com/2018/11/30/politics/north-carolina-electionresults-delay $>$ (last accessed December 21, 2018).

${ }^{10}$ For North Carolina's rules on mail-in absentee voting, see $<$ https://www.ncsbe.gov/absentee-voting-mail > (last accessed January 2, 2019).

${ }^{11}$ See Brian Murphy, Tim Funk, and Paul A. Specht, “'An Innocent Victim': Amid Election Fraud Claims, NC GOP Defends Mark Harris," News \& Observer, December 6, 2018, available at <https://www.newsobserver.com/news/politics-government/ article222751275.html > (last accessed December 20, 2018).

${ }^{12}$ See Eric Bradner et al., "Man at Center of North Carolina Election Fraud Probe Turned in Hundreds of Absentee Ballot Requests," CNN.com, December 5, 2018, available at <https:// www.cnn.com/2018/12/04/politics/north-carolina-house-racemccrae-dowless-absentee-ballots/index.html> (last accessed December 20, 2018).

${ }^{13}$ On 2014 and 2016, see Travis Fain, "Shadowy 9th District Figure Says He Took Cash in 2014 Election," WRAL.com, December 19, 2018, available at <https:/www.wral.com/ shadowy-9th-district-figure-says-he-took-cash-in-2014-election/ 18074896> (last accessed December 20, 2018), and Amy Gardner and Beth Reinhard, "N.C. Election Board's Warnings to Local and Federal Prosecutors About Alleged Election Fraud Drew Little Action," Washington Post, December 21, 2018 , available at $<$ https://www.washingtonpost.com/politics/nc-electionofficials-sounded-alarm-about-alleged-election-fraud-to-federalprosecutors-in-january-2017/> (last accessed December 26, 2018).

${ }^{14}$ On the primary, see Sydney Ember and Alan Blinder, "North Carolina Republican Says He Would Support New Election If Fraud Occurred," New York Times, December 7, 2018, available at <https://www.nytimes.com/2018/12/07/us/politics/northcarolina-absentee-ballots-fec-payment.html> (last accessed December 20, 2018). 2018 Republican primary election results are available at $<\mathrm{https}$ ://er.ncsbe.gov/?election_dt=05/ $08 / 2018 \&$ county_id $=0 \&$ office $=F E D \&$ contest $=0>$ (last accessed December 24, 2018). 


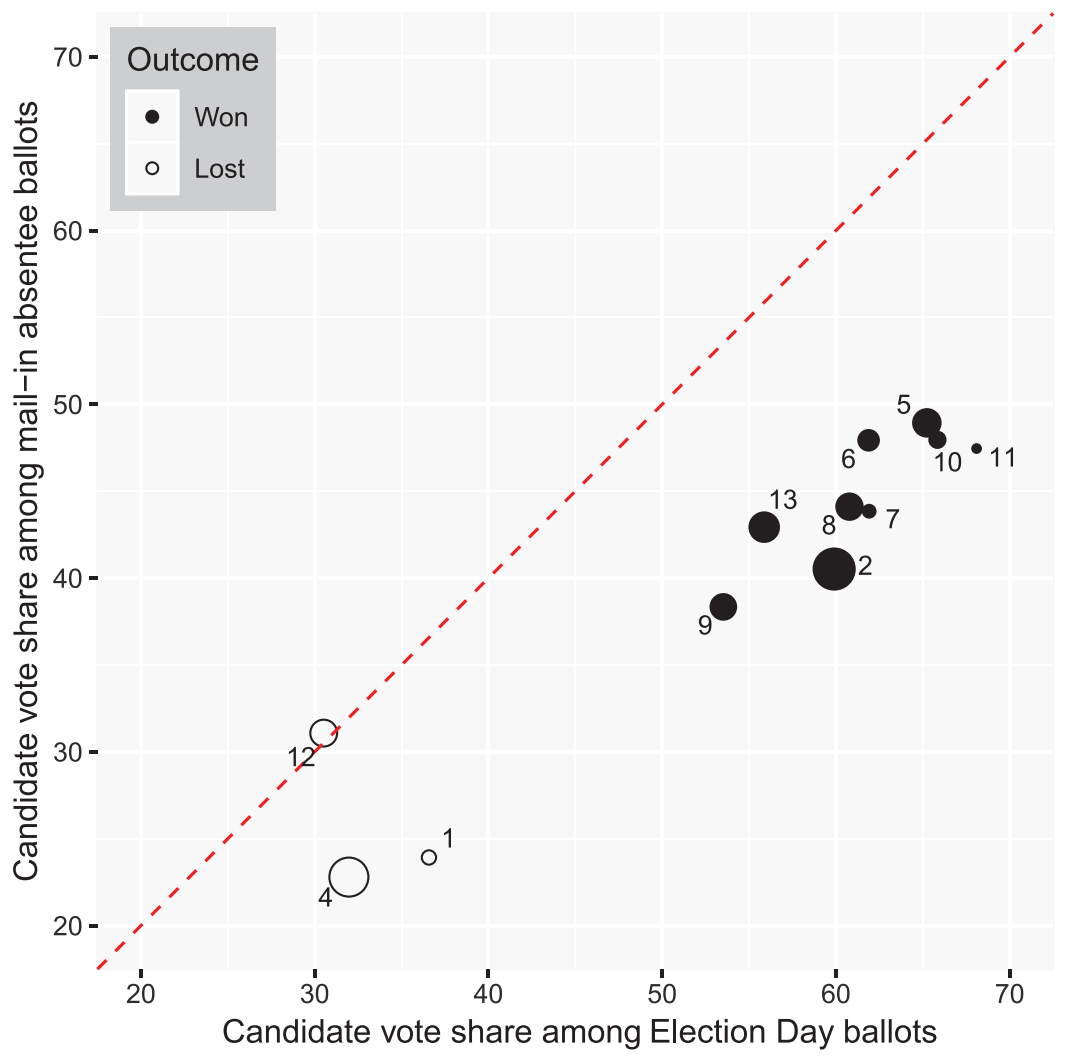

FIG. 1. Mail-in absentee and Election Day Republican vote shares in North Carolina congressional districts, 2018. Note: Points sized proportionally to sum of mail-in absentee and Election Day votes cast. Does not include District 3, which was uncontested.

fraud allegation was restricted to a single voting method.

If the alleged fraud took place, then the observed vote share for Mark Harris among mail-in absentee voters in North Carolina District 9 is higher than it should be. There were 10,651 mail-in absentee votes cast in this district in 2018, and Harris was selected on 4,027 of them, leading to a mail-in absentee vote share of approximately 38 percent. A key question is what this vote percentage would have been in the absence of mail-in absentee fraud, but this quantity is unobservable. Accordingly, we propose comparing Harris's mail-in absentee support to his Election Day support.

\section{Republican candidate support across congressional districts}

Figure 1 displays mail-in absentee and Election Day vote shares for the Republican candidates who contested congressional races in North Carolina in 2018. There are 12 points in the figure, one per contested congressional rate (District 3 is omitted). The figure also contains a dashed 45-degree line. District 12, whose point falls almost directly on this line, had approximately equal mail-in absentee and Election Day vote shares for its Republican candidate, Paul Wright. Like all districts, Mark Harris's District 9 is labeled in Figure 1, and Harris's absentee mail-in support rate-approximately 38 percent—can be seen by looking leftward from point " 9 " in this figure. ${ }^{15}$

Nothing is particularly remarkable about Figure 1's two clusters of points - one for winning Republican candidates (solid points), the other for losing candidates (open points). ${ }^{16}$ Beyond this, Figure 1 does show that, across congressional races in North Carolina, voting method tends to be associated with

\footnotetext{
${ }^{15}$ All North Carolina election results used in this study were downloaded from <https://er.ncsbe.gov/downloads.html> (last accessed December 26, 2018). The county-level results reported on were, when necessary, aggregated up from precinct-level return files.

${ }^{16}$ One could perhaps argue that Congressional District 12, which is contained in Mecklenburg County, appears slightly anomalous in Figure 1. However, there are no credible allegations associated with this district.
} 


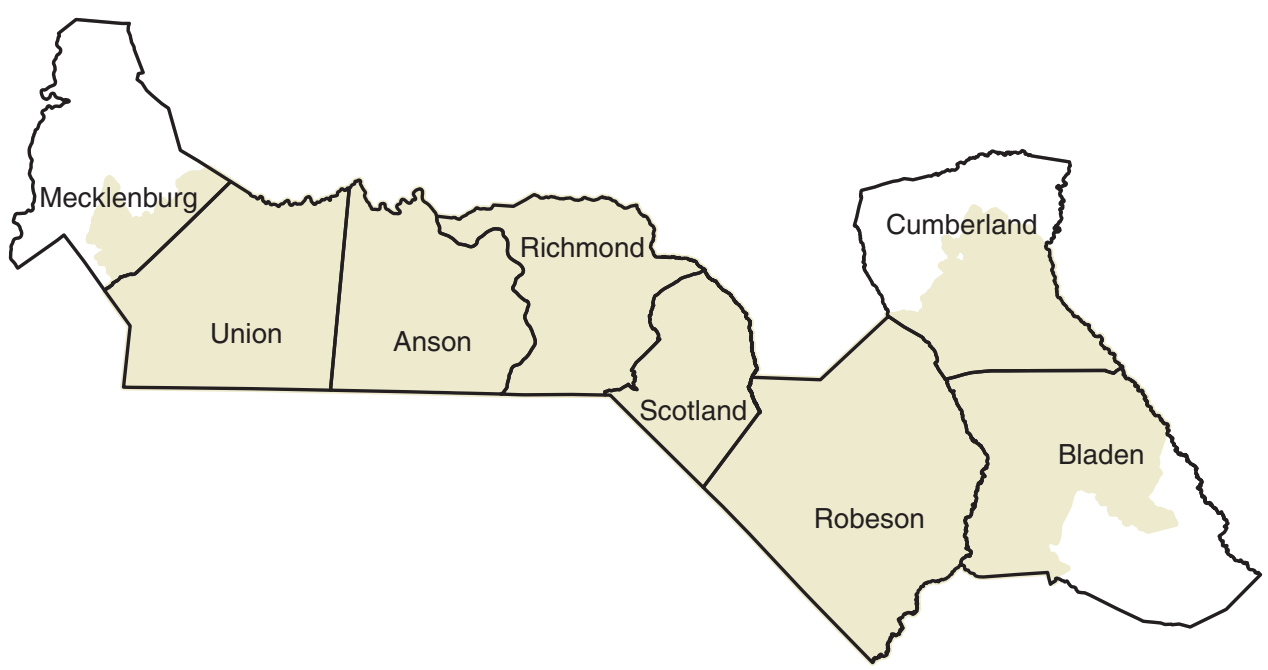

FIG. 2. Congressional District 9 with its eight intersecting counties. Note: Black borders are county boundaries with shading outlining the 9th Congressional District.

candidate support. In particular, Republican congressional candidates in 2018 tended to be more popular among Election Day voters than among mail-in absentee voters, and this follows from the fact that almost all of Figure 1's points are below the dashed 45-degree line in the figure. That voters sort themselves by partisanship and method of voting is neither new nor problematic (e.g., Herron and Smith 2012).

Across North Carolina, Congressional District 9 was the least pro-Republican of Republicanwinning congressional districts in $2018 .{ }^{17}$ In this district, Mark Harris received approximately 54 percent support among Election Day voters in the district, and 54 is certainly much greater than 38, Harris's vote share among mail-in absentee voters. Recall that a 54 versus 38 comparison is potentially useful insofar as an elevated mail-in absentee rate in favor of Harris could be problematic in light of fraud allegations. Overall, though, 38 percent is much lower than 54, and one would not think, on the basis of Figure 1, that the 9th Congressional District in North Carolina is particularly anomalous.

Because it displays congressional district results, Figure 1 aggregates over North Carolina's 100 counties. The reasons that this might be important are threefold. First, counties vary in their social and political makeup, and aggregating over counties might mask variance in candidate support rates by county. Second, election administration in North Carolina is conducted at the county level, as is common across the United States. If there are fraud al- legations directed at one race in particular, it is natural to examine variance in vote shares at the county level. Third, Figure 1 does not provide a way to standardize the gap-38 percent versus 54 percent-between Mark Harris's mail-in absentee and Election Day support rates. An Election Day vote share sufficiently different than 38 percent might be puzzling, but it is not clear from Figure 1 how high 38 would have to go before it would be considered anomalously high.

\section{Republican candidate vote shares within counties}

We now disaggregate our congressional district results by county. To provide some intuition for what this means, Figure 2 displays a map of North Carolina's 9th Congressional District.

As the map shows, there are eight counties that contribute to this district. All of Robeson County lies within it, and hence we say that there is only one 9th Congressional District/county intersection that includes Robeson. The same is true for Anson, Richmond, Scotland, and Union counties. However, as evidenced by the shading in Figure 2, Bladen County intersects both Congressional District 7 and District 9, and thus we say that there

\footnotetext{
${ }^{17}$ Here we use the word "winning" to refer to the fact that Mark Harris received more votes than Dan McCready in the 2018 North Carolina midterm. As noted in note 6, supra, however, there is no official winner of the Congressional District 9 race that took place in November 2018, and there never will be.
} 


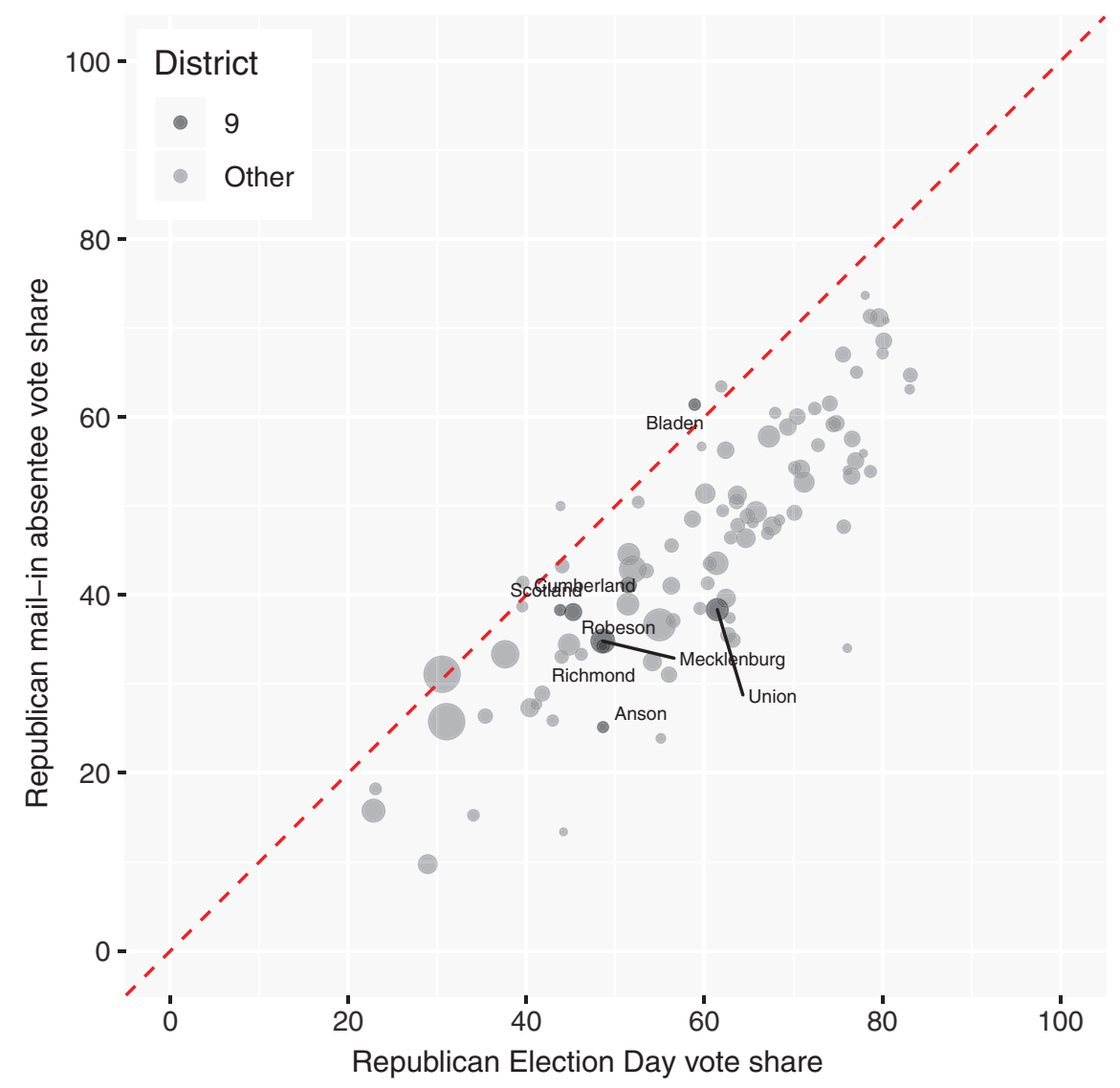

FIG. 3. Mail-in absentee and Election Day Republican vote shares in North Carolina congressional district/county intersections, 2018. Note: Points are sized proportionally to sum of mail-in absentee and Election Day votes cast. Does not include District 3 , which was uncontested.

are two congressional district/Bladen county intersections. Similar statements hold for Cumberland and Mecklenburg Counties.

Ignoring the uncontested District 3, Figure 3 describes 96 congressional district/county intersections in North Carolina from the 2018 midterm. The eight black points in the figure indicate sections of counties (or complete counties, like Robeson as discussed above) that intersect North Carolina's 9th Congressional District. The points are sized based on mail-in absentee plus Election Day turnout, and thus larger points are more informative. Finally, Figure 3's dashed 45-degree line describes the extent to which, in any district/county pair, the Republican mail-in absentee vote share for a Republican candidate differed from the candidate's Election Day vote share.

The black Bladen County point (mail-in absentee vote share of 61.4 percent) in Figure 3 lies above the figure's other black points, and from this it follows that, among counties intersecting the 9th Congres- sional District, Bladen County's mail-in absentee vote share for Mark Harris is greater than any other county's comparable vote share. However, the black Bladen County point in Figure 3 is not above all of the points in the figure. That is, while Figure 3 shows that Mark Harris received a high level of mail-in absentee support in Bladen County compared to how he performed in other counties that intersect the 9th District, Republican congressional candidates in 12 congressional district/ county intersections in North Carolina in 2018 performed better than Mark Harris in mail-in absentee balloting. The gray points in Figure 3 connoting these district/county intersections represent North Carolina's 5th, 6th, 10th, and 11th Congressional Districts.

While Figure 3 suggests that Bladen County may be anomalous vis-à-vis mail-in absentee voting, this conclusion is potentially confounded by a reliance on county-based comparisons. To wit, Mecklenburg County, which like Bladen County also intersects 

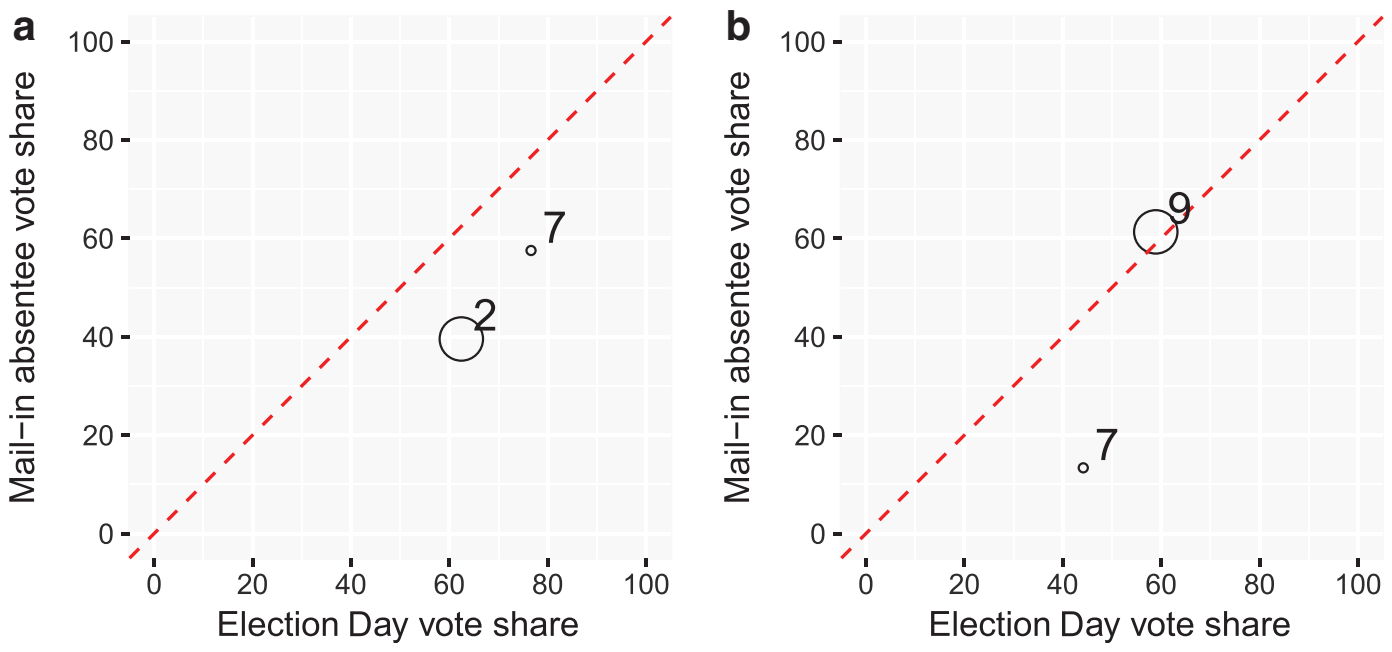

FIG. 4. Republican vote shares in (a) Johnston and (b) Bladen Counties, 2018.

North Carolina's 9th Congressional District, contains Charlotte, the largest city in North Carolina, and as of 2017 was home to slightly more than one million residents. We should hesitate before assuming that voters in Bladen and Mecklenburg have similar preferences for voting methods and/or 9th District congressional candidates. Union County, another county that intersects District 9 in North Carolina, is also larger and more racially homogeneous than Bladen. Our general point here is that comparisons across counties of mail-in absentee support rates for congressional candidates risk being confounded by county heterogeneity.

\section{Congressional district/county intersections}

As an initial motivation for our difference-indifference statistic, which we explain soon, Figure 4 disaggregates for two counties in North Carolina 2018 midterm congressional elections results by congressional district/county intersections. In particular, Figure $4 \mathrm{a}$ describes the vote shares of two Republican candidates whose congressional districts intersect Johnston County, and Figure 4b is similar but conditions on Bladen County.

The labeling in Figure 4's left panel reflects the fact that Johnston County intersects North Carolina Congressional Districts 2 and 7 with more voters in the former than the latter; note that Figure 4a's District 2 point is larger than the District 7 point. The identities of the Republican candidates in District 2 (George Holding) and District 7 (David Rouzer) are not as important as the fact that the abso- lute value of the difference in the two candidates' mail-in absentee vote shares is approximately 18 percentage points. Moreover, the absolute value of the difference between the candidates' Election Day vote shares is approximately 14 percentage points. The difference between these two differences is approximately four percentage points. Thus, while David Rouzer in District 7 outperformed fellow Republican George Holding in District 2 among Johnston County's mail-in absentee voters and Election Day voters, Rouzer's advantage over Holding was not appreciably large.

The same cannot be said about the two Republican congressional candidates in Bladen County, whose vote shares are depicted in Figure 4b. Here, Mark Harris, the Congressional District 9 candidate about whom we have already written, vastly outper formed David Rouzer among mail-in absentee voters. However, these two candidates were much closer among Election Day voters in Bladen County. The comparable difference-in-difference for Figure $4 \mathrm{~b}$ is 33.4 percentage points, more than eight times greater than the Johnston County difference-in-difference of four percentage points.

\section{A DIFFERENCE-IN-DIFFERENCE STATISTIC BASED ON METHOD OF VOTING}

To generalize the logic employed above, let $\operatorname{Rep}_{i, c}^{\text {Mail }}$ denote the Republican vote percentage 
among mail-in absentee votes of congressional candidate $i$ in county $c$. And, let $\operatorname{Rep}_{i, c}^{\mathrm{ED}}$ denote the same quantity but for election day voting. Then,

$$
\operatorname{AEDID}_{i, j, c}=\left|\operatorname{Rep}_{i, c}^{\mathrm{Mail}}-\operatorname{Rep}_{j, c}^{\mathrm{Mail}}\right|-\left|\operatorname{Rep}_{i, c}^{\mathrm{ED}}-\operatorname{Rep}_{j, c}^{\mathrm{ED}}\right|
$$

where $\operatorname{AEDID}_{i, j, c}$ is the difference in county $c$ in the absolute difference between candidate $i$ 's and candidate $j$ 's mail-in Absentee support and the absolute difference between candidate $i$ 's and $j$ 's Election Day support. The statistic AEDID (dropping subscripts for simplicity) is fundamental to much of the analysis that follows.

Several points about AEDID are worth noting. First, it is calculated as a within-county measure. Thus, the interpretation of this statistic relies on a maintained hypothesis that voters are sufficiently homogeneous within counties. While this assumption is not foolproof, it is weaker, and thus better, than assuming homogeneity across the state of North Carolina (this form of homogeneity is implied when, say, one compares mail-in absentee vote shares of candidates in different congressional races). Second, AEDID can only be calculated in a county which intersects multiple congressional districts. If a county is entirely subsumed in a single district, which is often the case when a state features many more counties than congressional districts, then AEDID cannot be applied in the county. Third, AEDID uses absolute differences in mail-in absentee and Election Day vote percentages, as opposed to differences, because we do not want to impose any directionality in our comparisons of candidates' mail-in absentee and Election Day vote shares. Fourth, implicit in a comparison of AEDID across multiple counties is the maintained hypothesis that, on average, campaigns do not differ across counties in the relative effort that they put into recruiting mail-in absentee and Election Day voters.

What can we make of the two values of AEDID based on Figure 4? The value of 33.4 (Bladen County) is indeed greater than four (Johnston County), but how much greater? It is possible that an AEDID value like 33.4 is a moderate one, broadly considered, but it is also possible that 33.4 is extreme, thus lending credibility to allegations that something untoward regarding mail-in absentee votes occurred in North Carolina's 9th Congressional District in 2018. Put another way, is the difference between 33.4 and four large enough to make one concerned that Mark Harris's mail-in absentee vote share in Bladen County was anomalous?

The answer to this question depends on the underlying distribution of AEDID, and ultimately this distribution will reflect how North Carolina voters sort themselves into counties and methods of voting and the extent to which counties are politically homogeneous. With respect to the latter point, county homogeneity is not to be taken lightly, and values of AEDID that are far from zero can reflect within-county differences. Any study of the distribution of AEDID needs to be attuned to this possibility and in particular cognizant that extreme values of AEDID in large counties should be understood as less meaningful than the same values in smaller counties.

\section{Anomalous congressional election results in the 2018 midterm}

To address the question of whether the value 33.4 of AEDID in Bladen County lies in the tails of the distribution of AEDID or in the middle of the support of this statistic, we calculate the empirical distribution of AEDID in the 2018 midterm election in North Carolina using the election returns that support Figure 5. This figure contains 12 panels, one for each county in North Carolina that intersected at least two congressional districts (ignoring the uncontested District 3). Most of North Carolina's 100 counties are not present in Figure 5, and this is because some counties in North Carolina are contained within a single congressional district. We have already noted that one cannot calculate AEDID for a county that intersects only one such district.

With the evident exception of Catawba County, the pictured counties in Figure 5 illustrate a notable regularity: conditional on county, a Republican congressional candidate who outperforms a competitor candidate via mail-in absentee voting also tends to outperform this individual on Election Day. It is also apparent from Figure 5 that the points in Bladen County's panel of Figure 5 are aligned differently than the pairs of points in the figure's other 11 panels.

To make this discussion precise, we order the 12 values of AEDID based on Figure 5, and these appear in Figure 6. This latter figure shows that mail-in absentee and Election Day returns for the Republican congressional candidates in Bladen 


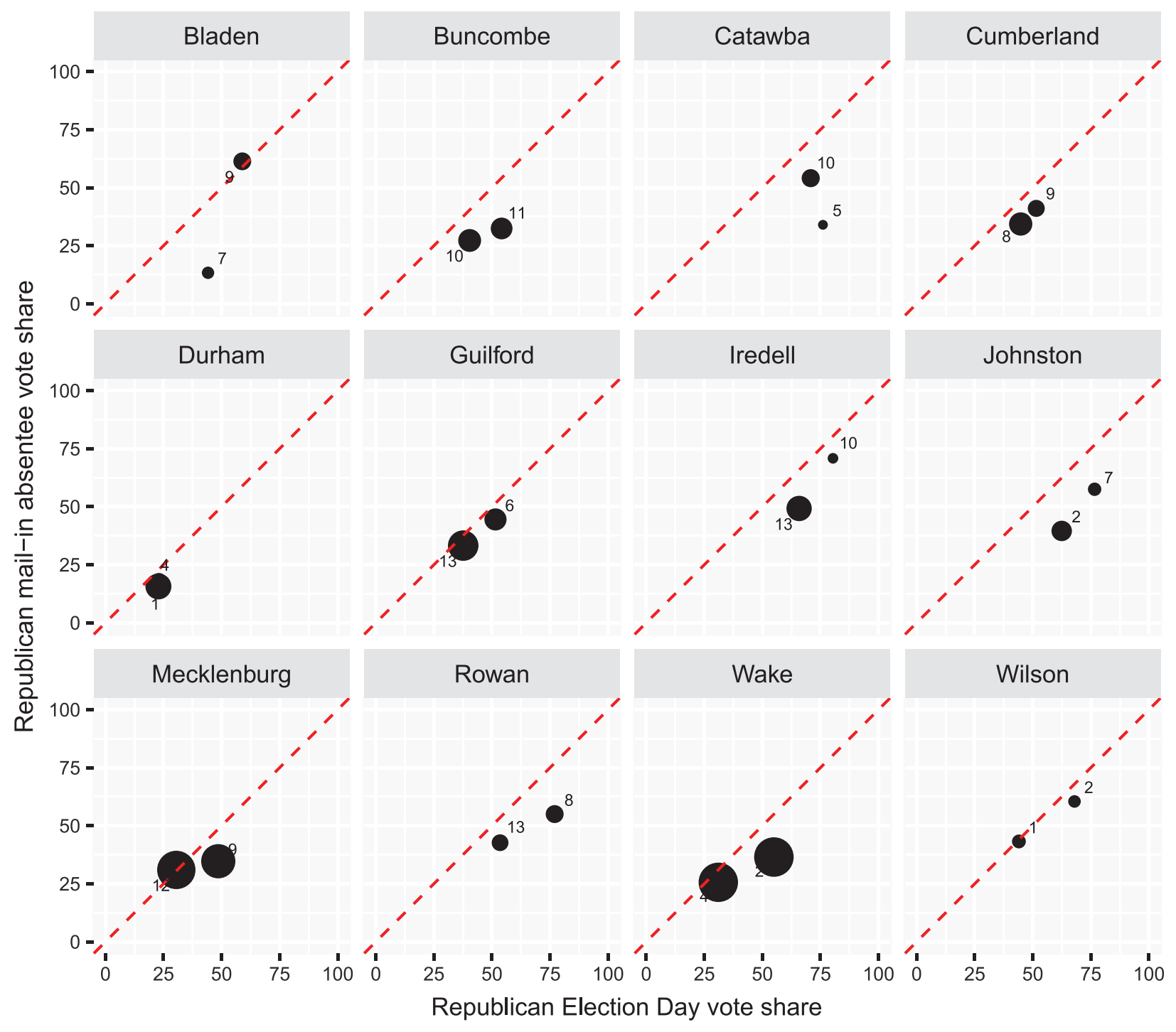

FIG. 5. Election Day and absentee Republican vote shares in North Carolina in counties intersecting at least two contested congressional races, 2018. Note: Points sized proportionally to total absentee and Election Day turnout. The figure does not include District 3, which was uncontested.

County are relatively anomalous in the sense of one candidate—namely, Mark Harris—having unusually strong mail-in absentee support compared to his Election Day support.

While Bladen County appears anomalous in Figure 6, it is possible that 2018 is a typical election year in North Carolina in the sense of featuring at least one county with unusual congressional election returns. Perhaps, that is, every election in the state contains a county, or even a small set of counties, in which a pair of congressional candidates whose Election Day vote shares are roughly similar have mail-in absentee vote shares that diverge. Put another way, Figure 6 could reflect the result of selecting an unusual pair of congressional rates in a single county for analysis without taking into consideration the fact that every election with enough jurisdictions-here, North Carolina counties-will feature an extreme result or two.

\section{Recent congressional elections in North Carolina}

To investigate the possibility that every North Carolina election has a county as extreme as Bladen County was in 2018, Figure 7 plots for the 2010, 


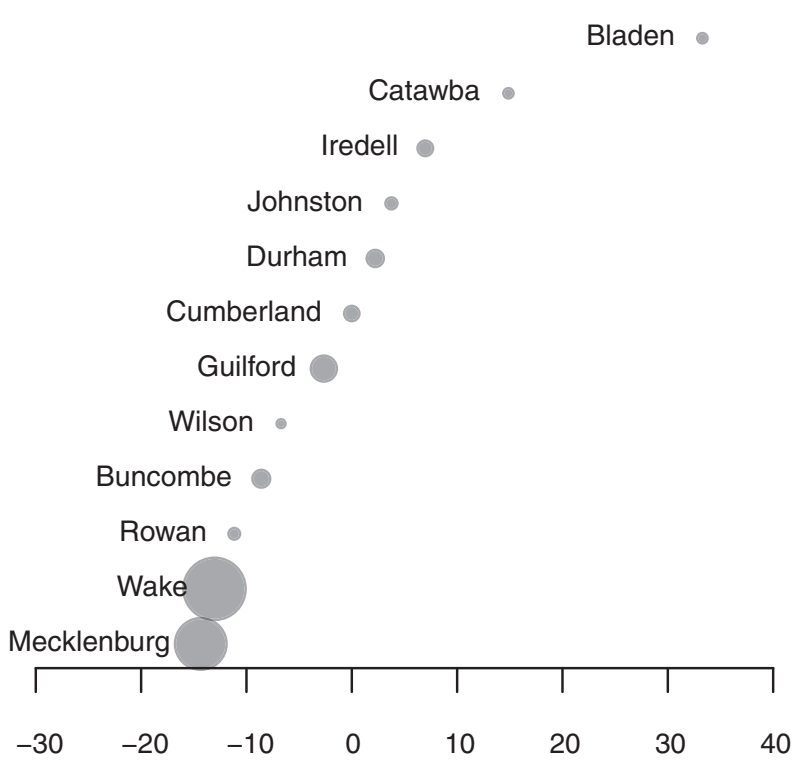

FIG. 6. Distribution of AEDID across North Carolina counties, 2018 midterm election. Note: Points sized proportionally to total absentee turnout.

2012, 2014, 2016, and 2018 general and midterm elections values of AEDID for all counties in North Carolina that intersected at least two contested congressional districts. We define a congressional race as contested if it had at least two official candidates. Some North Carolina congressional races in our period of analysis had one official candidate plus a write-in candidate, and we consider such races to be uncontested. There are 181 total points in the figure. ${ }^{18}$

If a North Carolina county intersected three or more contested congressional districts, which did not happen in 2016 but did in 2014, then this county contributes more than one value of AEDID to Figure 7. In particular, a county intersecting $k$ districts with contested congressional races has $\left(\begin{array}{l}k \\ 2\end{array}\right)$ pairs of districts whose mail-in absentee and Election Day support levels can be compared via AEDID.

Two features of Figure 7 stand out. First, Bladen County's 2018 value of AEDID (green point) is the most extreme value of this statistic across the North Carolina congressional election cycles of 2010 through the present. In other words, Mark Harris's mail-in absentee vote share in 2018 is the greatest such vote share when compared to mail-in absentee and Election Day vote shares of other congressional candidates whose districts intersected North Carolina counties. Second, Bladen County's 2016 value of AEDID (orange point) is extreme albeit not quite as extreme as its 2018 version. Mark Harris

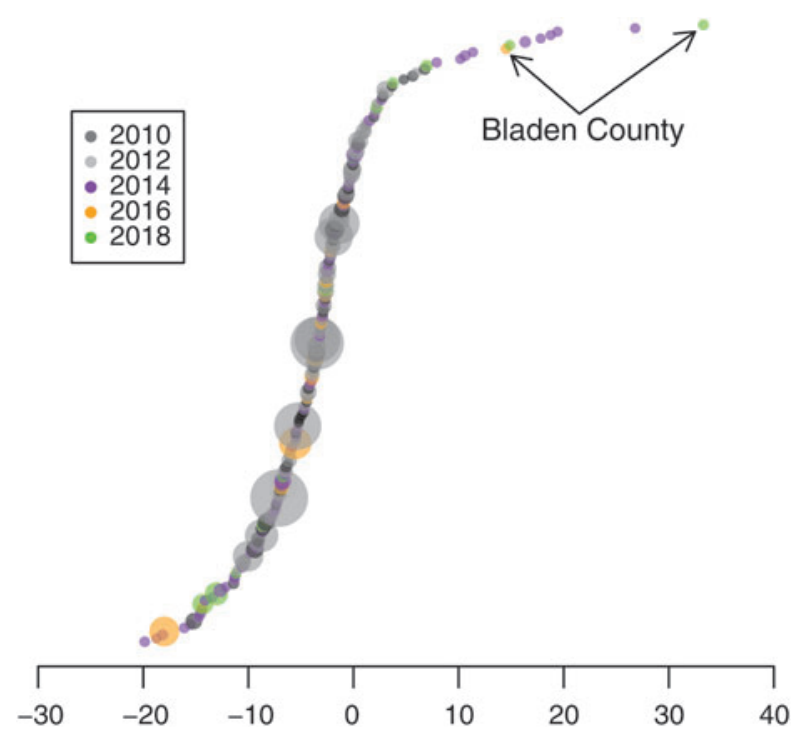

FIG. 7. Values of AEDID across North Carolina elections of 2010, 2012, 2014, 2016, and 2018. Note: Points sized proportionally to total absentee turnout.

was not a candidate in the 9th Congressional District race in 2016, which was contested by Republican Robert Pittenger and Democrat Christian Cano. Our finding that Bladen County appears anomalous in 2016 is notable insofar as fraud investigations in the aftermath of the 2018 midterm election raised questions about Bladen County and in particular whether the 2016 midterm election in this county was, like its 2018 counterpart, unduly affected by absentee ballot improprieties.

Table 1 lists the ten most anomalous-meaning large values of AEDID-congressional district/ county intersections that are visually displayed in Figure 7. For each entry, the table lists election year, county, the two involved congressional districts, the total number of absentee votes cast in the two districts, and the associated value of AEDID.

Bladen County appears in the table twice, once for 2018 and once for 2016. In both cases, the

\footnotetext{
${ }^{18}$ Since the post-2010 Census redistricting period, congressional districts in North Carolina have been the subject of a variety of legal disputes involving gerrymandering. These legal entanglements are not part of the analysis here. See Robert Barnes, "North Carolina's Gerrymandered Map Is Unconstitutional, Judges Rule, and May Have to Be Redrawn Before Midterms," Washington Post, August 27, 2018, available at <https://www .washingtonpost.com/politics/courts_law/2018/08/27/fc04e066aa46-11e8-b1da-ff7faa680710_story.html> (last accessed December 25, 2018).
} 
Table 1. Ten Most Anomalous North Carolina Congressional District/County Pairs

\begin{tabular}{llcrl}
\hline Year & County & Districts & Absentee votes & AEDID \\
\hline 2018 & Bladen & 7,9 & 841 & 33.29 \\
2014 & Granville & 6,13 & 150 & 26.80 \\
2014 & Granville & 1,13 & 204 & 19.42 \\
2014 & Vance & 1,13 & 156 & 18.76 \\
2014 & Gates & 1,3 & 35 & 17.81 \\
2014 & Mecklenburg & 8,12 & 890 & 16.33 \\
2018 & Catawba & 5,10 & 899 & 14.87 \\
2016 & Bladen & 7,9 & 144 & 14.51 \\
2014 & Lenoir & 3,7 & 1,210 & 1.36 \\
2014 & Alamance & 2,6 & & 10.62 \\
\hline
\end{tabular}

involved congressional districts are the same: the 7th and 9th. Bladen County notwithstanding, the next most extreme entries in Table 1 generally consist of relatively small counties from the 2014 midterm election. To the best of our knowledge, there are no fraud allegations associated with mail-in absentee voting in the 2014 counties listed in Table 1. Moreover, four of the counties saw very few mail-in absentee votes, meaning that the values of AEDID from these counties are not particularly meaningful. Mecklenburg County in 2014 appears in Table 1, and there were 1,990 mail-in absentee ballots in the county's 8th and 12th Congressional Districts that year. While this county is relatively anomalous, its 2014 value of AEDID is half of Bladen County's value in 2018.

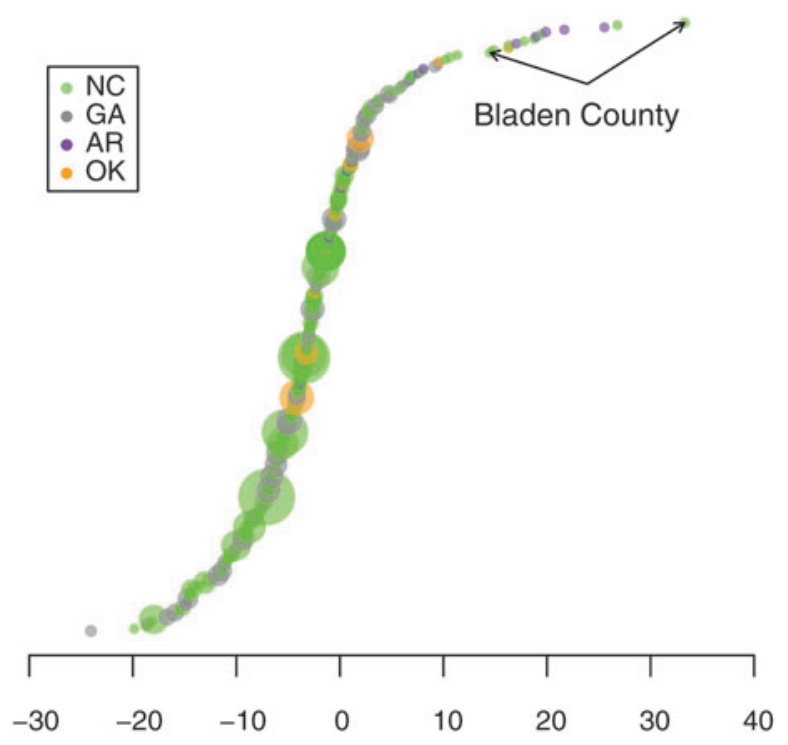

FIG. 8. Values of AEDID across Arkansas (AR), Georgia (GA), North Carolina (NC), and Oklahoma (OK) elections. Note: Points sized proportionally to total absentee turnout.

\section{Congressional elections in other states}

Republican congressional candidate Mark Harris's 2018 rate of mail-in absentee support in Bladen County was anomalously high, and we have ruled out the possibility that this rate is typical among North Carolina congressional contests. However, selecting on North Carolina is not necessarily ideal. It is possible that each state in the United States contains a puzzling congressional election (i.e., a large value of AEDID) every few years, in which case Bladen County's results in 2018 may simply be North Carolina's contribution to 2018's set of unusual congressional election outcomes.

With this as background, Figure 8 displays North Carolina values of AEDID across congressional elections along with values of AEDID for Arkansas, Georgia, and Oklahoma for the general and midterm elections of 2012, 2014, 2016, and 2018. ${ }^{19}$ These three states all maintain publicly available election records with which one can calculate mail-in absentee and Election Day candidate support rates by congressional districts within county. Each of the 264 points in the figure represents a county in one of the four named states that intersects at least two congressional districts with contested races. Points are colored by state and sized based on absentee votes cast. ${ }^{20}$

Figure 8 reinforces what we observed when considering North Carolina alone. Namely, the mail-in

\footnotetext{
${ }^{19}$ For Arkansas election data, see <https://results.enr.clarity elections.com/AR/>; for Georgia data, see $<$ http://results.enr .clarityelections.com/GA/>; and, for Oklahoma data, see $<$ https:// www.ok.gov/elections/Election_Info/Election_Results/index .html> (all sites last accessed December 26, 2018).

${ }^{20}$ Neither Arkansas nor Georgia maintain the necessary data for the 2010 midterm election to be included in Figure 8. Oklahoma does maintain such data, but to maintain consistency with Arkansas and Georgia, we restrict attention to elections in this state starting with 2012.
} 
absentee vote share for Republican congressional candidate Mark Harris in Bladen County in the 2018 midterm election in North Carolina was extreme when compared to Harris's Election Day vote share. Based on the statistic AEDID, Harris's 2018 Bladen County mail-in absentee support was more extreme than the mail-in absentee support for any other comparable congressional candidates in any of the recent elections in the four states covered in Figure 8. Moreover, Bladen County's mailin absentee voting patterns in the 2016 midterm election were also rather anomalous when placed in the context of other states.

\section{Mail-in versus one-stop absentee voting}

Using a difference-in-difference statistic applied in congressional election results we have thus far focused on contrasts between mail-in absentee voting and Election Day voting. However, to the extent to that fraud affected the former method of voting in Congressional District 9 in 2018, we might expect to observe a contrast between mail-in absentee voting and one-stop absentee voting there as well. Moreover, one advantage of comparing mail-in and one-stop absentee voting is that these two methods of casting ballots are both pre-Election Day. If there were significant efforts to increase voter turnout in Congressional District 9 in 2018, for example, then these efforts might confound our mail-in absentee versus Election Day comparisons. The same cannot be said about a comparison between mailin and one-stop absentee voting.

That said, we now define a modified version of AEDID based on mail-in and one-stop absentee voting:

$$
\begin{aligned}
\operatorname{AEDID}_{i, j, c}= & \left|\operatorname{Rep}_{i, c}^{\text {Mail }}-\operatorname{Rep}_{j, c}^{\text {Mail }}\right| \\
& -\left|\operatorname{Rep}_{i, c}^{\text {One-stop }}-\operatorname{Rep}_{j, c}^{\text {One-stop }}\right|
\end{aligned}
$$

For North Carolina congressional elections of 2010 through 2018, Figure 9 plots values of the modified AEDID. Bladen County is highlighted in this figure, which parallels the earlier Figure 7.

The key implication in Figure 9 is that Bladen County in 2018-represented by the rightmost point in Figure 9-is anomalous in the sense of having the greatest contrast in recent congressional contests between mail-in absentee and one-stop absentee voting: Bladen County's 2018 point in the figure is located at approximately 28.4, and the

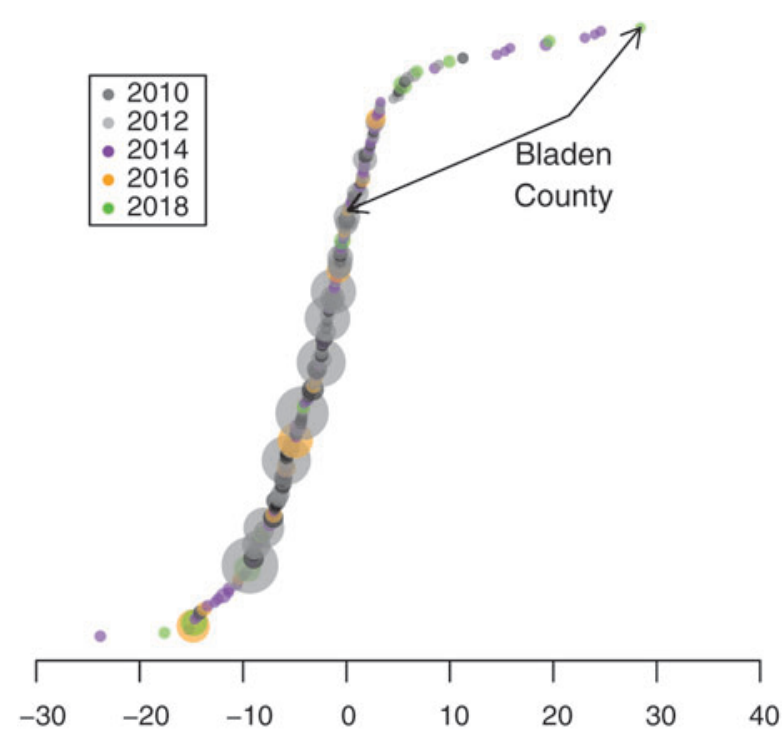

FIG. 9. Values of AEDID based on one-stop absentee voting. Note: Points sized proportionally to total one-stop.

next greatest point in magnitude is associated with Pitt County and has a modified AEDID value of approximately -23.8 . Given what we have already established about anomalous mail-in absentee voting in Bladen County, this is perhaps an intuitive finding. However, the finding is nonetheless notable insofar as it implies that our qualitative results on Bladen County in 2018 do not solely reflect our focus on a contrast between mail-in absentee and Election Day voting.

Regarding Bladen County in 2016, the corresponding point in Figure 9 is not anomalous (value is approximately 0.14). In fact, Bladen County in 2016 falls in the middle of the support of the modified AEDID. From this it follows that, among recent North Carolina congressional races, there is no evidence in Bladen County of a seemingly inexplicable contrast between mail-in absentee and one-stop absentee voting. This does not imply that Bladen County in 2016 was anomaly-free, but it does imply that evidence to the contrary cannot be found in a contrast between mail-in absentee and one-stop absentee voting in this county-year.

\section{North Carolina state legislative races}

As an illustration of the generality of our difference-in-difference statistic, and in addition to highlight the anomalous nature of North Carolina's 9th Congressional District in 2018, we now propose another slight modification of AEDID. We return 


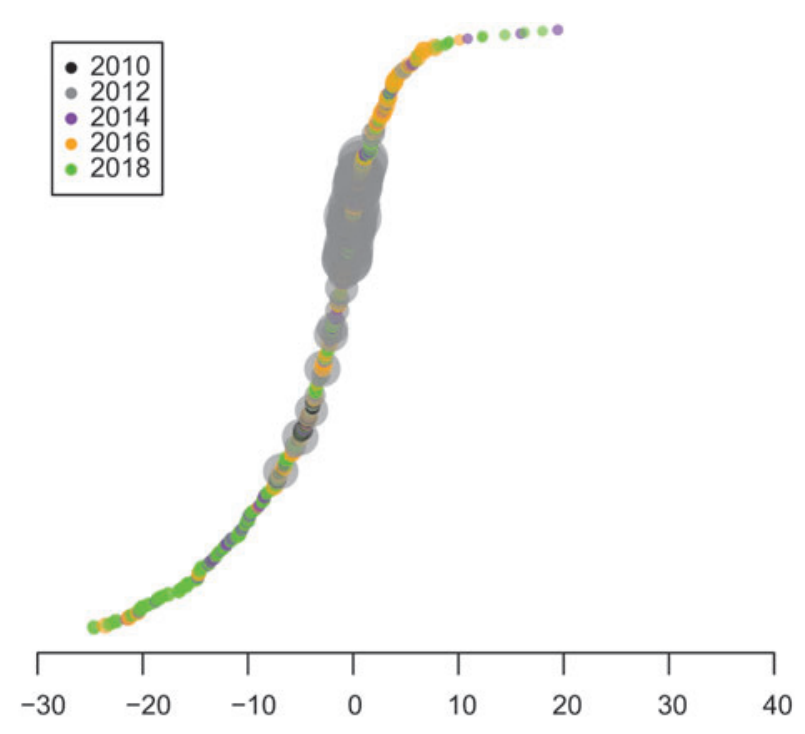

FIG. 10. Values of AEDID across North Carolina House elections. Note: Points sized proportionally to total absentee turnout. The point associated with Macon County House Districts 119 and 120 does not appear in the figure; there was only one mail-in absentee ballot cast in Macon County in District 119 and also only one mail-in absentee ballot in District 120 . In addition, North Carolina House races without official Republican candidates do not appear in the figure.

to defining AEDID based on mail-in absentee and Election Day vote percentages, but now we apply this statistic to North Carolina House races. There are 120 seats in the lower legislative chamber in North Carolina, and many associated districts cross county lines. This enables us to make withincounty comparisons of North Carolina House contests just as we have done with North Carolina congressional contests. Values of AEDID for North Carolina House elections from 2010 through 2018 appear in Figure 10.

There are 475 points in the figure, each of which represents a pair of contested North Carolina House races that split a county (contested races that lack Republican candidates are ignored). The range of AEDID in Figure 10 is approximately -24.6 to approximately 27.6. Recall that the value of AEDID for the 9th Congressional District in 2018 is 33.4. Thus, this latter race is not only anomalous compared to other congressional races in North Carolina (and beyond) in recent election years, but is also anomalous when compared to the many North Carolina House contests that have occurred since 2010.

The specifics of North Carolina state elections beyond the disputed contest in Congressional District 9 lie beyond our purview. Nonetheless, Figure 10 shows how our difference-in-difference statistic AEDID has utility as an election anomaly detector. Roughly speaking, it appears that values beyond 30 in magnitude are rare, and the rate at which these values appear is the subject of ongoing research.

\section{ADDITIONAL EVIDENCE ON THE ANOMALOUS NATURE OF THE 9TH CONGRESSIONAL DISTRICT IN NORTH CAROLINA}

Thus far we have argued using a variety of difference-in-difference statistics that North Carolina's 9th Congressional District race in the 2018 midterm elections was highly anomalous. Its extreme results are typical neither of historical congressional elections in North Carolina nor of historical congressional elections in other states. In what follows we now consider additional evidence on Congressional District 9. First, we use our differencein-difference approach to study recent congressional primary elections in North Carolina. Second, we consider mail-in absentee ballot request and return rates.

Congressional primary elections, 2016 and 2018

The voting fraud allegations motivating this study have also touched on North Carolina's 2018 congressional primaries. ${ }^{21}$ We now turn to these elections as well as to preceding primaries from 2016.

In the 2018 Republican primary, Mark Harris received 610 out of 811 total (approximately 75 percent) mail-in absentee votes cast, and Harris's nearest Republican competitor, then congressional incumbent Robert Pittenger, received only 186 (approximately 23 percent). Nonetheless, in Election Day voting, Harris and Pittenger were almost tied, Harris having received 4,907 Election Day votes (approximately 48.5 percent) to Pittenger's 4,710

\footnotetext{
${ }^{21}$ For details on allegations and the 2018 primary, see Amy Gardner and Kirk Ross, "North Carolina Election-Fraud Investigation Centers on Operative with Criminal History Who Worked for GOP Congressional Candidate," Washington Post, December 3, 2018, available at <https://www.washingtonpost .com/politics/north-carolina-election-fraud-investigationcenters-on-operative-with-criminal-history-who-worked-for-gopcongressional-candidate/2018/12/03/7b270a90-f6aa-11e8-8c9a860ce2a8148f_story.html> (last accessed December 25, 2018).
} 

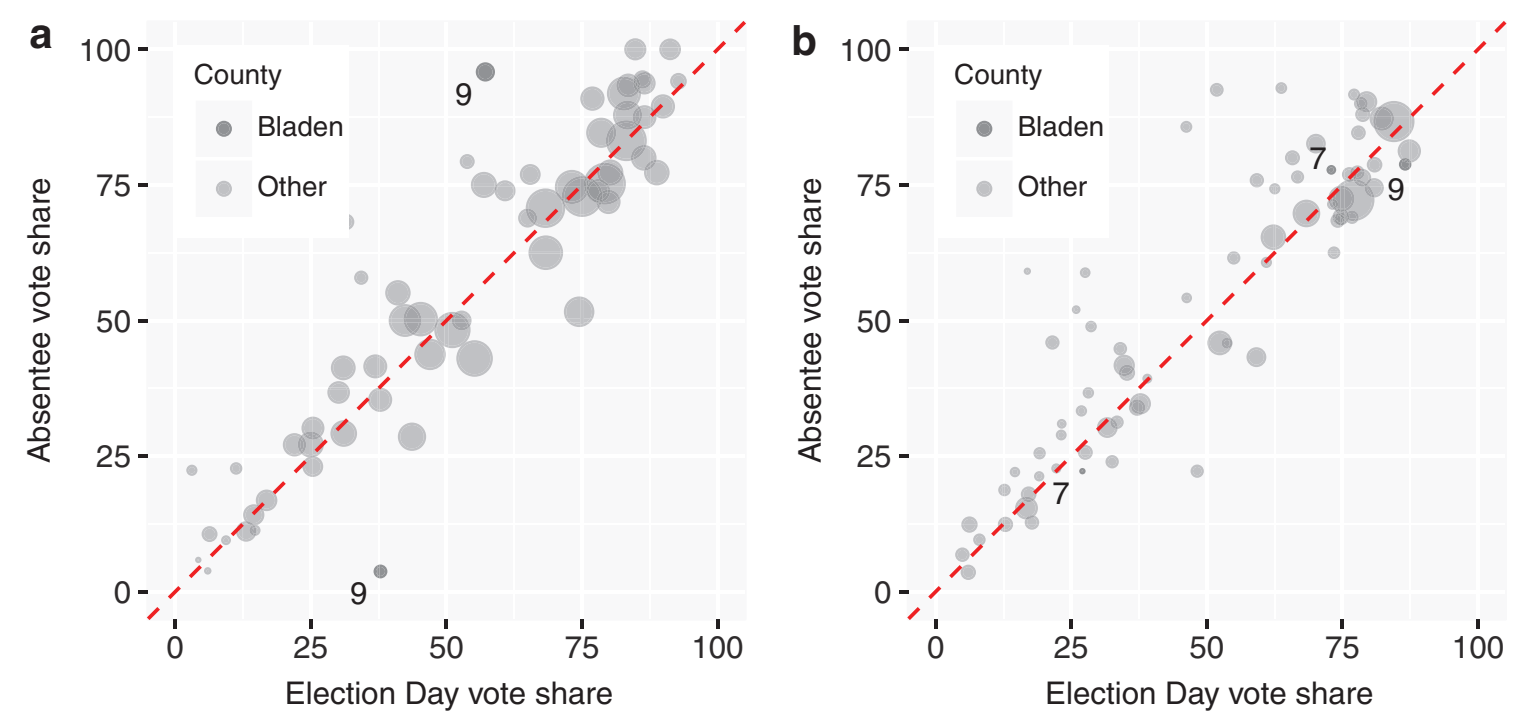

FIG. 11. Election Day and absentee vote shares in North Carolina congressional primaries, May 2018. (a) 2018 Republican Primary. (b) 2018 Democratic Primary. Note: Each point depicts election results for a congressional primary candidate in a single county who received at least 10 mail-in and at least 10 Election Day votes in the county. Point sizes are proportional to sum of mail-in absentee and Election Day votes a candidate received.

(approximately 46.6 percent) out of a total of 10,108 Election Day ballots. In a way that is parallel to the 2018 midterm election, Harris's advantage over Pittenger in the 2018 primary in mail-in absentee voting is large compared to his slight advantage on Election Day voting, and this motivates Figure 11, which plots by county mail-in absentee and Election Day vote shares for the Republican and Democratic candidates in their respective May 2018 primaries.

Figure 11a has 145 points and Figure 11b, 131 points, each of which corresponds to a congressional district/county intersection. There were many more 2018 primary election candidates than candidates in the later 2018 midterm. Some of the former, however, received very few votes. For example, Clarence W. Goins, Jr., competed in the Republican primary in Congressional District 9, receiving two mail-in absentee votes in Bladen County. To avoid confounding Figure 11 by candidate support rates that depend on a minuscule number of ballots cast, the figure includes only congressional district/county pairs in which a primary election candidate received at least 10 mail-in absentee and at least 10 Election Day votes.

Figure 11a highlights Bladen County in the May 2018 Republican Primary, and it shows visually the extent to which the two Republican candidates in Congressional District 9 were similar vis-à-vis Election Day vote share yet quite different with re- spect to mail-in absentee support. Indeed, one of these two candidates, Mark Harris, had a primary mail-in absentee vote share in Bladen County that was close to 100 percent.

Figure 11a shows as well that there were two congressional district/county intersections that featured a candidate who received literally 100 percent support within mail-in absentee ballots. Both of these intersections involve Congressional District 11, where there was a dominant candidate, Mark Meadows, who received approximately 86 percent support across his district. Disregarding District 11, Mark Harris's mail-in absentee support rate in the May 2018 Republican primary in Bladen County was the highest mail-in absentee support rate observed across all North Carolina congressional district/county intersections with at least a minimal number of votes.

In the May 2018 Democratic primary, which is presented in Figure 11b, Bladen County does not appear anomalous. One of the two Democratic candidates (Kyle Horton, upper-right corner of the figure) who competed in District 7 outperformed the other candidate (Grayson Parker, lower-left) in both mail-in absentee and Election Day voting. While Horton did have a high mail-in absentee support rate, this should not raise a red flag: Horton also had a high Election Day support rate. There were two Democratic District 9 candidates in Bladen 

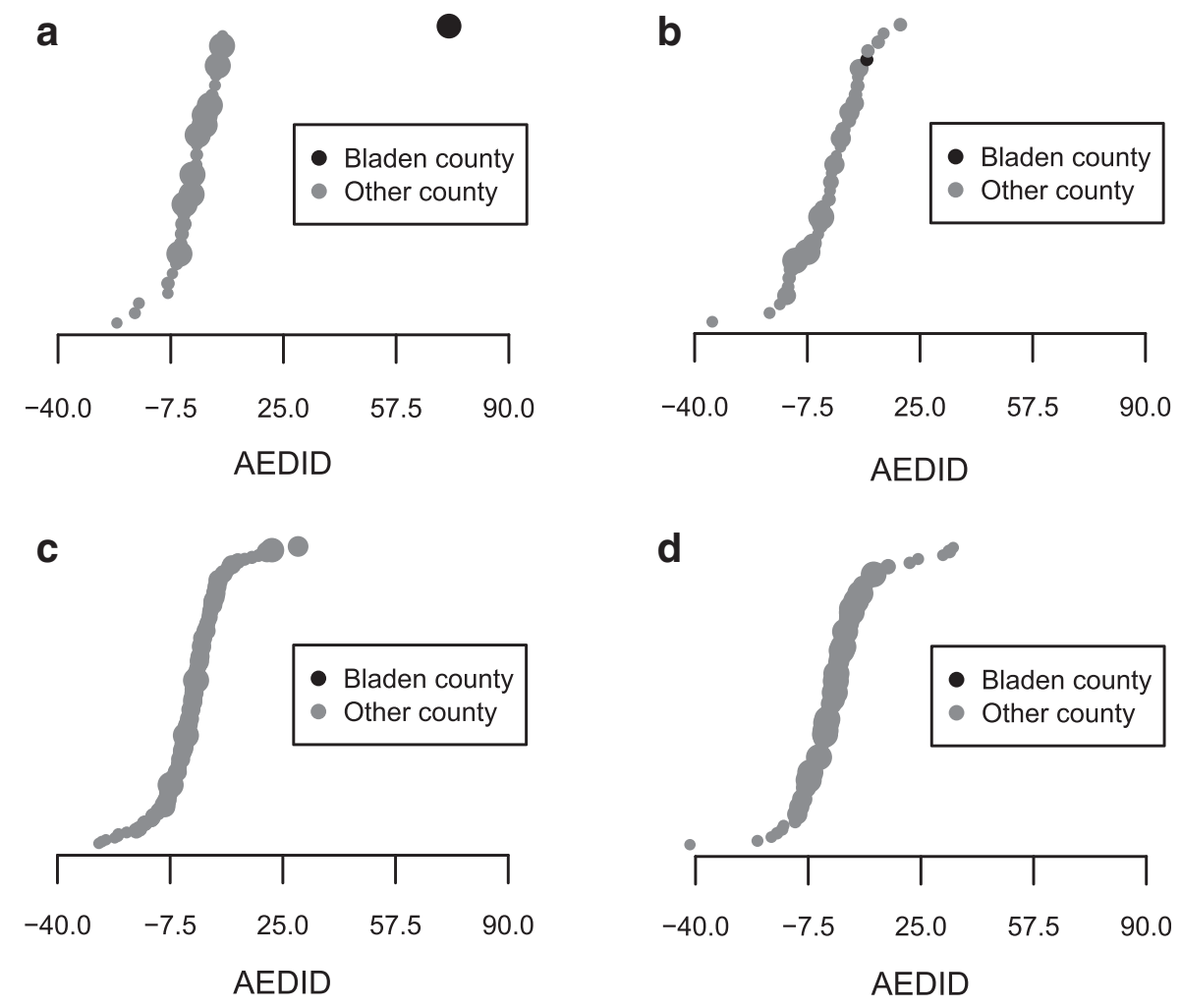

FIG. 12. Values of AEDID across 2016 and 2018 primary elections. (a) 2018 Republican Primary. (b) 2018 Democratic Primary. (c) 2016 Republican Primary. (d) 2016 Democratic Primary. Note: To be included in this figure, both involved congressional primary candidates must have received at least 10 mail-in and at least 10 Election Day votes in the county. Points are sized proportionally to total absentee votes cast in a congressional district/county intersection.

County, but one received a very small number (seven) of mail-in absentee votes and is thus not depicted in Figure 11b.

Figure 12 presents the distributions of AEDID for the Republican and Democratic primary elections in 2018 (upper panels) and 2016 (lower panels) in North Carolina. The four panels parallel earlier presentations of our difference-in-difference statistic.

Turning first to the 2018 Republican and Democratic primary elections in Figures $12 \mathrm{a}$ and $12 \mathrm{~b}$, respectively, one point stands out: Bladen County in the Republican contest in the 9th Congressional District. The value of AEDID in this county is highly anomalous, being several times greater than the values of AEDID for other congressional district/county combinations. The Bladen County value of AEDID in Figure 12b, pertaining to the Democratic primary, is not remarkable.

Figures 12c and 12d depict the 2016 Republican and Democratic primary elections, which took place on June 7, 2016. In the two figures, no congressional district/county intersection stands out as anomalous.
A Bladen County point does not appear in Figure 12c, but there was in fact a District 9 Republican Primary in 2016 that intersected this county. Contesting the primary were three candidates: Mark Harris, Robert Pittenger, and Todd Johnson. Robert Pittenger won, barely, with a combined vote share across the 9th District of 34.95 percent to Mark Harris's 34.45 percent. In Bladen County itself in 2016, there were 226 mail-in absentee votes cast in the Republican primary. Of these, four were for Harris, one for Pittenger, and 221 were for Johnson. There were also 419 Election Day votes cast in the primary, of which Harris received 149, Pittenger 44, and Johnson 226. Johnson's mailin absentee vote share in Bladen County was thus approximately 98 percent, and his Election Day vote share, approximately 54 percent.

That Johnson's 2016 Republican primary mail-in absentee vote share in Bladen County was almost twice his corresponding Election Day share is consistent with fraud allegations made in the aftermath of the 2018 midterm election. According to North Carolina investigators, Mark Harris was quoted in a text message stating that, "[T]he guy whose 

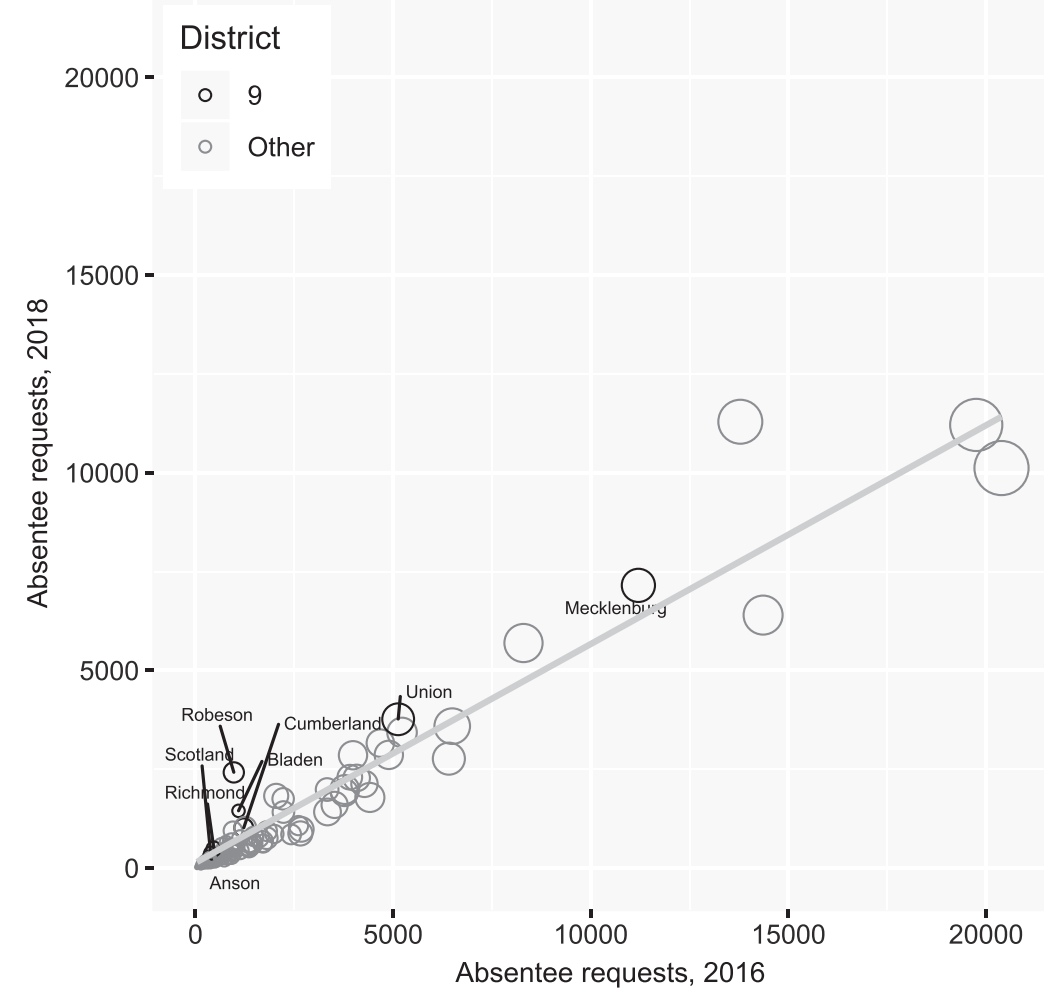

FIG. 13. Mail-in absentee ballot requests across North Carolina congressional district/county pairs, 2016 and 2018 . Note: Points sized based on total votes cast in the 2018 midterm election, and the figure's gray regression line is weighted by total votes cast.

absentee ballot project [in 2016] for [Todd] Johnson could have put me in the [U.S.] House this term, had I known, and he had been helping us." 22 Nonetheless, we previously set a limit of 10 on the number of mail-in absentee and Election Day votes required for a value of AEDID to be plotted in Figure 12c. The 2016 Republican Primary in Bladen County falls below this level because, of the three candidates contesting it, two had mail-in absentee vote totals less than 10 .

\section{Mail-in absentee ballot request and return rates in North Carolina, 2016 and 2018}

As a final look at the 9th Congressional District in North Carolina, we now turn to some specifics regarding absentee voting in this state. One reason that we do this is to address the possibility that an unusual pattern in voter mobilization is responsible for the mail-in absentee anomalies in Bladen County that we have noted throughout this article. While the North Carolina State Board of Elections has already decided to re-run the 9th Congressional District election and thus implicitly has dismissed a mobilization explanation for Bladen
County's anomalous vote returns, it is still important to consider this possibility.

Hypothetically, there are several ways that absentee ballot fraud in North Carolina's 9th Congressional District could have interfered with Mark Harris's mail-in absentee vote share in November 2018. One way is via tampering with requests for mail-in absentee ballots. A second way is via tampering of mail-in ballots after they have been requested. We address these two possibilities in order.

Mail-in absentee ballot requests. Registered voters in North Carolina who wish to vote mail-in absentee must formally request an absentee ballot via a State Absentee Ballot Request Form. Per the North Carolina State Board of Elections and Ethics Enforcement, "The State Absentee Ballot Request Form may only be signed by the voter or a nearrelative or legal guardian of the voter." 23

\footnotetext{
${ }^{22}$ See note 4, supra, for the origin of this quotation.

${ }^{23}$ For guidelines on North Carolina absentee ballot requests, see $<$ https://www.ncsbe.gov/absentee-voting-mail > (last accessed January 2, 2019).
} 


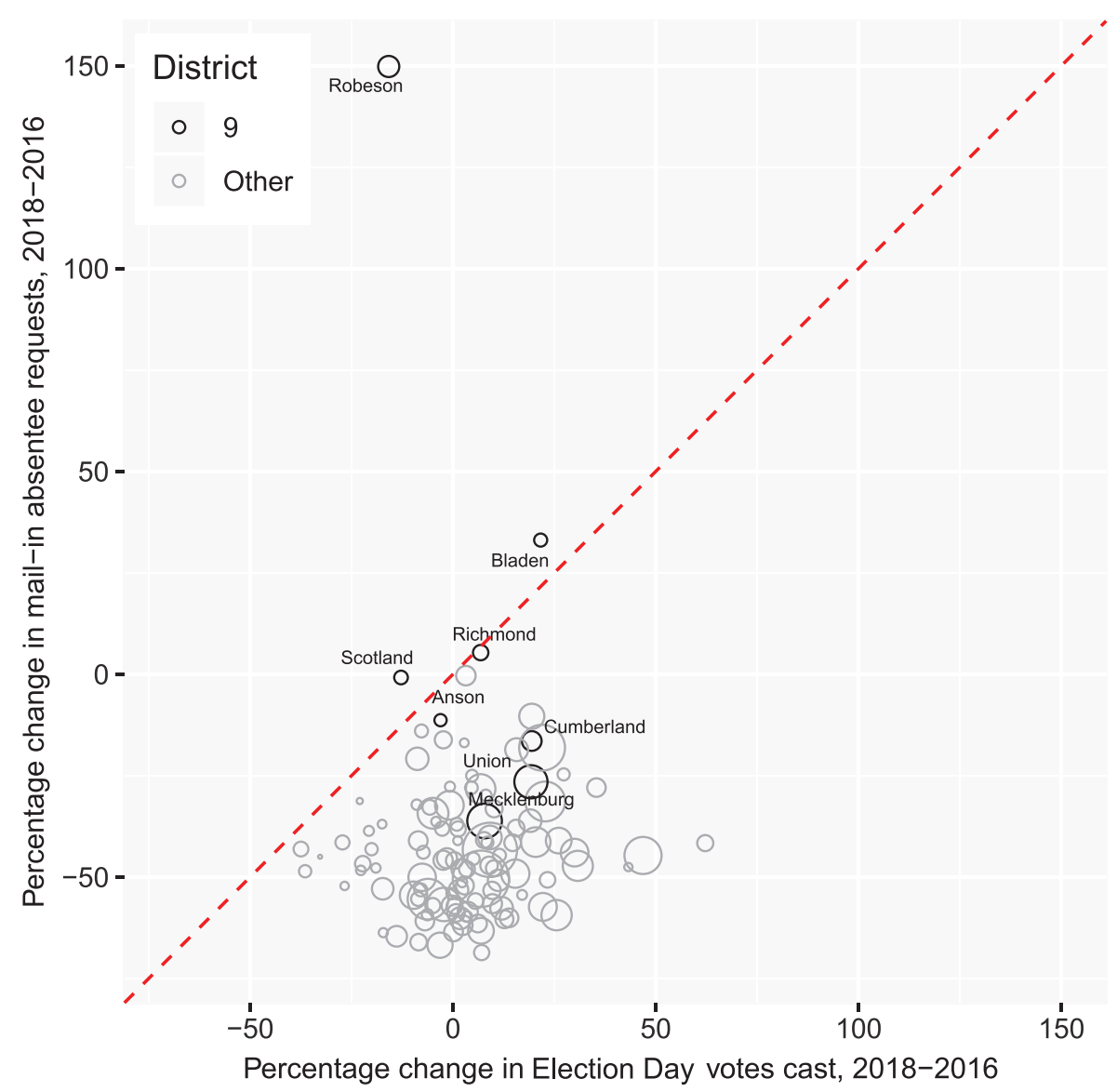

FIG. 14. Percentage changes in absentee ballot requests and Election Day voting across North Carolina congressional districts/ counties, 2016 and 2018. Note: Points sized based on total votes cast in the 2018 midterm election.

To assess whether in the 2018 midterm election there were anomalies in absentee ballot request rates in North Carolina, we need to establish a baseline for comparison. With that in mind, Figure 13 shows total absentee requests in North Carolina by congressional district/county intersections for the 2018 midterm and a baseline election, the 2016 general. As in previous figures, each point in Figure 13 is either an entire county or the part of a county that intersects a congressional district. In the figure, black points indicate district/county intersections that include the 9th Congressional District.

Ideally, Figure 13 would incorporate as a baseline the 2014 midterm election. However, North Carolina's congressional districts were adjusted between 2014 and 2016, and this complicates comparisons between 2014 and 2018 congressional districts in the state. ${ }^{24}$

Figure 13 shows there were more mail-in absentee requests in the period surrounding the 2016 general election than in the period surrounding the 2018 midterm. This is perhaps not surprising insofar as the former election included a presidential contest. Second, there was a fair bit of regularity from 2016 to 2018 in mail-in absentee requests rates in North Carolina, as shown in the clustering of points around the superimposed regression line in the figure (regression is weighted by total votes cast in 2018). And third, the majority of the congressional district/county intersections that include the 9th Congressional District lie below the regression line. The Robeson County point is particularly distant from the solid gray line in Figure 13.

A limitation in Figure 13, though, is that it could be confounded by temporal changes, 2016 to 2018, in county-level political activity. As the figure

\footnotetext{
${ }^{24}$ For the legislative history of the redistricting that affected congressional district boundaries used in the 2016 General Election, see S.B. 2, available at <https://www.ncleg.gov/ BillLookup/2015E1/sb2> (last accessed January 2, 2019).
} 
Table 2. Ten North Carolina Congressional District/County Pairs with the Greatest Absentee Ballot Increases, 2016-2018

\begin{tabular}{lccrr}
\hline County & District & Requests 2016 & Requests 2018 & Percentage change \\
\hline Robeson & 9 & 971 & 2,426 & 149.85 \\
Bladen & 9 & 1,091 & 1,452 & 33.09 \\
Richmond & 9 & 467 & 492 & 5.35 \\
Franklin & 2 & 951 & 948 & -0.32 \\
Scotland & 9 & 384 & 381 & -0.78 \\
Johnston & 2 & 2,044 & 1,833 & -10.32 \\
Anson & 9 & 336 & 298 & -11.31 \\
Yancey & 11 & 665 & -13.97 \\
Columbus & 7 & 669 & 561 & -16.14 \\
Cumberland & 9 & 1,224 & 1,023 & -16.42 \\
\hline
\end{tabular}

shows, Robeson County in Congressional District 9 saw many mail-in absentee ballot requests in 2018 . This could in principle reflect voter mobilization efforts in Robeson County.

To address potential confounding by mobilization, Figure 14 adopts a difference-in-difference approach and plots for the 2016 general and 2018 midterm percentage changes in Election Day votes (vertical axis) against percentage changes in absentee requests (horizontal axis). In this figure, points are again colored black for Congressional District 9 , and the figure includes a dashed 45-degree line.

The implications of Figure 14 are twofold. First, the vast majority of congressional district/county intersections in North Carolina saw large percentage drops in absentee requests between 2016 and 2018 yet small changes in Election Day turnout. This is evident in the clustering of gray points in the neighborhood of -50 (horizontally) and zero (vertically). Second, the 9th Congressional District does not follow this pattern. Its intersecting counties combined large percentage changes in absentee ballot requests with small changes in Election Day turnout. Robeson County is an exemplar of this with Bladen County (the part that intersects Congressional District 9) the next most extreme location.

The placement of 9th Congressional District points in Figure 14 is not consistent with a political mobilization explanation for the large increase in mail-in absentee ballot requests in Robeson and Bladen Counties. For this explanation to be compelling, the points associated with these two counties would have had to have been much higher vertically in the figure.

Table 2 lists the 10 congressional district/county intersections with the largest percentage change in absentee ballot requests, 2016 to 2018 . Of the inter- sections, six are from the 9th Congressional District. Moreover, as is clear from raw request numbers, Table 2's large percentage changes in mail-in absentee ballot requests are not artifacts of small changes that, in percentage terms, are large.

Mail-in absentee ballot return rates. We now turn our attention to absentee ballot return rates, a subject that appears to have received little attention in the literature on election administration. For the purposes of this study, we say that a mail-in absentee ballot in North Carolina was returned if it was marked as "Accepted" by the state after having been sent out to a registered voter. ${ }^{25}$ Figure 15 plots mailin absentee ballot return rates for North Carolina congressional district/county intersections in 2016 and 2018. These years were part of our analysis, above, of mail-in absentee ballot requests.

The eight counties that intersect Congressional District 9 are noted in Figure 15, and these intersections had relatively low mail-in absentee ballot return rates in 2018. Robeson County is the most anomalous: the 2018 mail-in absentee ballot rate in Robeson was less than 30 percent despite the fact that almost 70 percent of requested mail-in absentee ballots were returned in 2016. Bladen County is also anomalous: it suffered a sizable drop in absentee ballot returns in 2018 compared to 2016.

\footnotetext{
${ }^{25}$ To determine the number of accepted mail-in ballots, we downloaded the files "absentee_20161108.zip" after selecting the 11/08/2016 election then choosing Available Electionrelated Files and "absentee_20181106.zip" after selecting the 11/06/2018 election and then choosing Available Election-related Files from <https://er.ncsbe.gov/downloads.html> (last accessed January 6, 2019). These two individual-level files have a column, "ballot_rtn_status," which specifies whether a mail-in absentee ballot was accepted.
} 


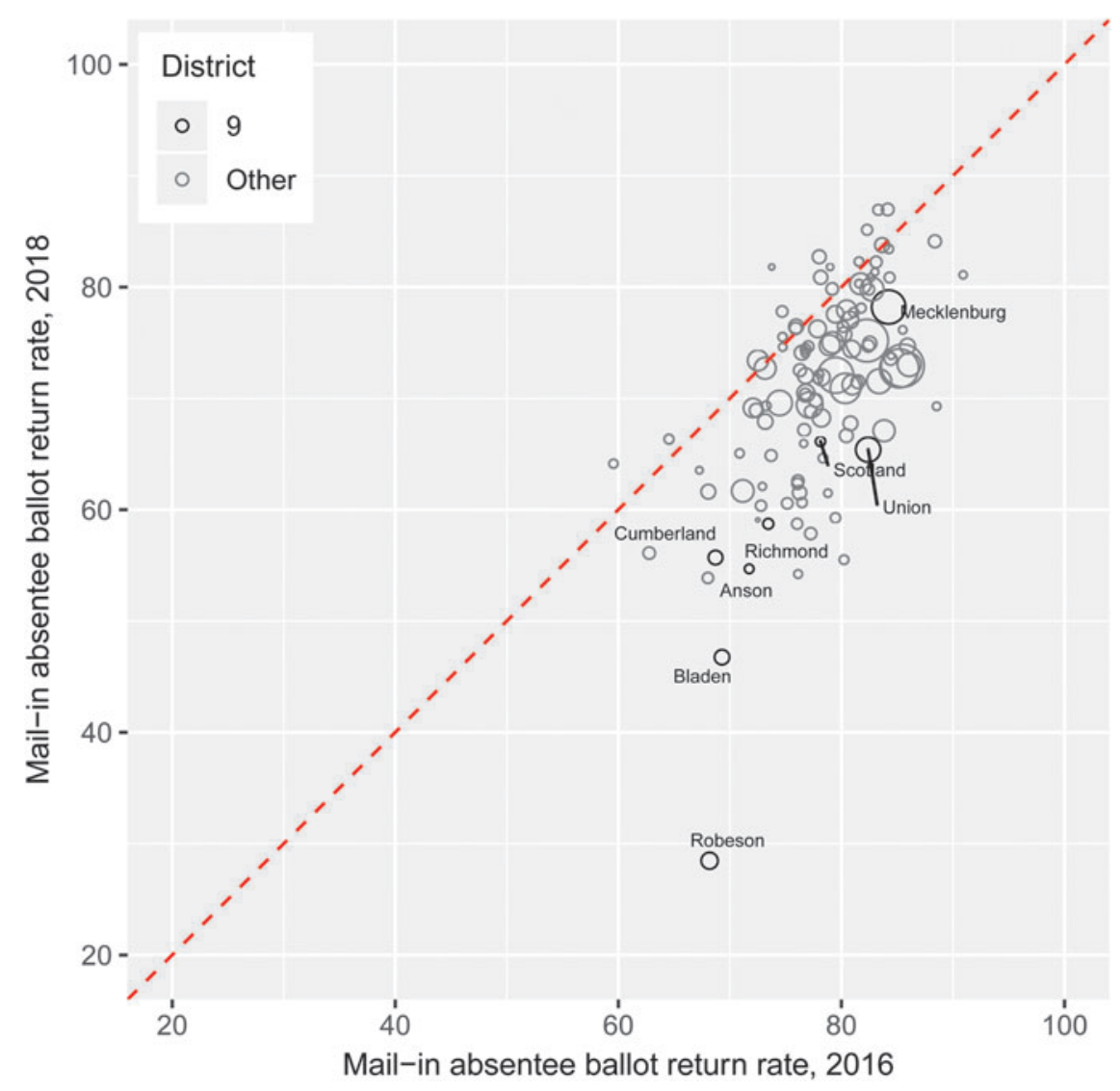

FIG. 15. Mail-in absentee ballot return rates across North Carolina congressional district/county intersections, 2016 and 2018. Note: Points sized proportionally to the sum of mail-in absentee ballot requests across 2016 and 2018 .

Based on publicly available information, we cannot classify non-returned, mail-in absentee ballots as simply discarded by requesting voters, lost, stolen, illegally collected and subsequently discarded, or something else entirely. Accordingly, we cannot determine why exactly there were so few returned mail-in absentee ballots in 2018 among counties that touch the 9th Congressional District. Whatever the reason, though, this district is anomalous in its absentee ballot return rates in a way that is consistent with allegations of absentee ballot abnormalities.

\section{DISCUSSION}

Allegations about mail-in absentee voter fraud in the 9th Congressional District in North Carolina marred the aftermath of the 2018 midterm election. Republican Mark Harris, who per original vote totals won the 9th District race, filed a lawsuit in January 2019 in the Wake County Superior Court, requesting certification of his victory. ${ }^{26}$ However, following a formal investigation, which corroborated concerns that had been publicly aired in late 2018, the North Carolina State Board of Elections voted unanimously in February 2019 to hold a new election in the 9th Congressional District.

How can scholars and election officials use publicly available information from the 2018 midterm to assess whether the 9th Congressional District in North Carolina contest was anomalous in a way consistent with fraud claims? The answer to that question has implications for North Carolina in particular and for research efforts aimed at uncovering election abnormalities in general. This study shows how a difference-in-difference statistic based on the presence of multiple congressional districts in

\footnotetext{
${ }^{26}$ The text of Harris's filing is available at $<\mathrm{https}: / /$ mediaweb .wsoctv.com/document_dev/2019/01/03/Mark\%20Harris\%20files \%20petition_14139653_ver1.0.pdf> (last accessed January 5, 2019).
} 
a single county can shed light on the extent to which a congressional candidate (or a congressional primary candidate) had excessive mail-in absentee ballot support. We computed versions of our statistic for multiple North Carolina midterm and general elections since 2010, for different methods of voting, across several other states in this same time period, and for the 2016 and 2018 congressional primary elections in North Carolina. In all of these cases, Bladen County stands out as anomalous: there are inconsistencies in this county between mail-in absentee ballot vote shares for Republican congressional (or primary) candidates and their Election Day support rates.

Bladen County is not alone in the 9th Congressional District in the extent to which it is anomalous. A neighboring county, Robeson, had both an anomalously high mail-in absentee ballot request rate in the 2018 midterm election and then an anomalously low ballot return rate. Bladen County also had unusual request and return rates for mail-in absentee ballots. Overall, compared to other counties in North Carolina, those that intersect the 9th Congressional District had extreme mail-in absentee ballot request and return patterns.

As a final note, the improprieties that, per the North Carolina State Board of Elections, occurred in Bladen and Robeson Counties in the 2018 midterm election are not of the type most associated with public concerns about election fraud. As discussed in Cottrell, Herron, and Westwood (2018), these concerns generally turn on matters like ineligible voting and not on the extent to which mailin absentee balloting makes the American election system vulnerable to fraud. Given the expansion across the United States of voting by mail, notably in Oregon and Washington, the events in North Carolina's 9th Congressional District pose a challenge for state and local officials who manage elections and mail-in absentee ballot casting in particular.

\section{REFERENCES}

Ahlquist, John S., Kenneth R. Mayer, and Simon Jackman. 2014. "Alien Abduction and Voter Impersonation in the 2012 U.S. General Election: Evidence from a Survey List Experiment." Election Law Journal 13(4): 460-475.

Ansolabehere, Stephen and Nathaniel Persily. 2008. "Vote Fraud in the Eye of the Beholder: The Role of Public Opinion in the Challenge to Voter Identification Requirements." Harvard Law Review 121(7): 1737-1774.
Arkansas Secretary of State. 2018. "Election List: Election Night Reporting." URL: <https://results.enr.clarityelections .com/AR/> (last accessed December 26, 2018).

Barnes, Robert. 2018. "North Carolina's Gerrymandered Map Is Unconstitutional, Judges Rule, and May Have to Be Redrawn Before Midterms.” Washington Post. August 27. URL: <https://www.washingtonpost.com/politics/courts_ law/2018/08/27/fc04e066-aa46-11e8-b1da-ff7faa680710_ story.html> (last accessed December 25, 2018).

Beber, Bernd and Alexandra Scacco. 2012. "What the Numbers Say: A Digit-Based Test for Election Fraud." Political Analysis 20(2): 211-234.

Blinder, Alan. 2019. "New Election Ordered in North Carolina Race at Center of Fraud Inquiry." New York Times. February 21. URL: <https://www.nytimes.com/2019/02/21/us/ mark-harris-nc-voter-fraud.html $>$ (last accessed February 22, 2019).

Bradner, Eric, Adam Levy, Drew Griffin, and Curt Devine. 2018. "Man at Center of North Carolina Election Fraud Probe Turned in Hundreds of Absentee Ballot Requests." CNN.com. December 5. URL: <https://www.cnn.com/2018/ $12 / 04 /$ politics/north-carolina-house-race-mccrae-dowlessabsentee-ballots/index.html> (last accessed December 20, 2018).

Cottrell, David, Michael C. Herron, and Sean J. Westwood. 2018. "An Exploration of Donald Trump's Allegations of Massive Voter Fraud in the 2016 General Election." Electoral Studies 51: 123-142.

Deckert, Joseph, Mikhail Myagkov, and Peter C. Ordeshook. 2011. "Benford's Law and the Detection of Election Fraud." Political Analysis 19(3): 245-268.

Ember, Sydney, and Alan Blinder. 2018. "North Carolina Republican Says He Would Support New Election If Fraud Occurred." New York Times. December 7. URL: <https:/www.nytimes.com/2018/12/07/us/politics/northcarolina-absentee-ballots-fec-payment.html $>$ (last accessed December 20, 2018).

Fain, Travis. 2018. "Shadowy 9th District Figure Says He Took Cash in 2014 Election." WRAL.com. December 19. URL: $<$ https://www.wral.com/shadowy-9th-district-figure-sayshe-took-cash-in-2014-election/18074896> (last accessed December 20, 2018).

Frisina, Laurin, Michael C. Herron, James Honaker, and Jeffrey B. Lewis. 2008. "Ballot Formats, Touchscreens, and Undervotes: A Study of the 2006 Midterm Elections in Florida." Election Law Journal 7(1): 25-47.

Gardner, Amy and Beth Reinhard. 2018. "N.C. Election Board's Warnings to Local and Federal Prosecutors About Alleged Election Fraud Drew Little Action." Washington Post. December 21. URL: <https://www.washingtonpost.com/ politics/nc-election-officials-sounded-alarm-about-allegedelection-fraud-to-federal-prosecutors-in-january-2017/> (last accessed December 26, 2018).

Gardner, Amy and Kirk Ross. 2018. "North Carolina ElectionFraud Investigation Centers on Operative with Criminal History Who Worked for GOP Congressional Candidate." Washington Post. December 3. URL: <https://www .washingtonpost.com/politics/north-carolina-election-fraudinvestigation-centers-on-operative-with-criminal-history-whoworked-for-gop-congressional-candidate/2018/12/03/ 
7b270a90-f6aa-11e8-8c9a-860ce2a8148f_story.html> (last accessed December 25, 2018).

Georgia Secretary of State. 2018. "Election List: Election Night Reporting." URL: <http://results.enr.clarityelections.com/ GA/> (last accessed December 26, 2018).

Harris v. North Carolina Bipartisan State Board of Elections and Ethics Enforcement. 2019. Petition for Writ of Mandamus and Appeal from the Failure of State Board to Act. No. 19CV000025. January 3. URL: <https://mediaweb.wsoctv .com/document_dev/2019/01/03/Mark\%20Harris\%20files\%20 petition_14139653_ver1.0.pdf> (last accessed January 5, 2019).

Hasen, Richard L. 2018. "The 2016 Voting Wars: From Bad to Worse.” William \& Mary Bill of Rights Journal 26(3): 629655.

Herron, Michael C. and Daniel A. Smith. 2012. "Souls to the Polls: Early Voting in Florida in the Shadow of House Bill 1355." Election Law Journal 11(3): 331-347.

Investigation of Election Irregularities Affecting Counties Within the 9th Congressional District. 2019. Order of the North Carolina State Board of Elections. March 13. URL: <https://dl.ncsbe.gov/State_Board_Meeting_Docs/ Congressional_District_9_Portal/Order_03132019.pdf> (last accessed April 18, 2019).

Katz, Richard S. 1997. Democracy and Elections. Oxford, UK: Oxford University Press.

Levy, Adam. 2018. "North Carolina Elections Board Delays Certification of Congressional Election Results Again," CNN.com. December 3. URL: <https://www.cnn.com/2018/ 11/30/politics/north-carolina-election-results-delay> (last accessed December 21, 2018).

Mebane, Jr., Walter R. 2004. "The Wrong Man is President! Overvotes in the 2000 Presidential Election in Florida." Perspectives on Politics 2(3): 525-535.

Mebane, Jr., Walter R. 2011. "Comment on 'Benford's Law and the Detection of Election Fraud." Political Analysis 19(3): 269-272.

Medzihorsky, Juraj. 2015. "Election Fraud: A Latent Class Framework for Digit-Based Tests.” Political Analysis 23(4): 506-517.

Minnite, Lorraine C. 2010. The Myth of Voter Fraud. Ithaca, NY: Cornell University Press.

Murphy, Brian, Tim Funk, and Paul A. Specht. 2018. “'An Innocent Victim': Amid Election Fraud Claims, NC GOP Defends Mark Harris." News \& Observer. December 6. URL: <https://www.newsobserver.com/news/politicsgovernment/article222751275.html> (last accessed December 20, 2018).

Murphy, Brian, Jim Morrill, and Ely Portillo. 2019. “John Harris Warned His Father About Legal Red Flags Involving Bladen Operative." News \& Observer. February 20. URL: <https://www.newsobserver.com/news/politics-government/ article226492265.html> (last accessed February 20, 2019).

North Carolina State Board of Elections. 2018. "05/08/2018 Official Local Election Results-Statewide.” URL: $<$ https:// er.ncsbe.gov/?election_dt=05/08/2018\&county_id=0\&office $=$ FED\&contest $=0>$ (last accessed December 24, 2018).

North Carolina State Board of Elections. 2018. "11/06/2018 Official General Election Results—Statewide.” URL: <https:// er.ncsbe.gov/?election_dt=11/06/2018\&county_id=0\&office= FED\&contest $=1183>$ (last accessed December 20, 2018).

North Carolina State Board of Elections. 2018. "Civilian Absentee Voting Instructions.” URL: <https://www.ncsbe .gov/absentee-voting-mail> (last accessed January 2, 2019).

North Carolina State Board of Elections. 2018. "Election Downloads." URL: <https://er.ncsbe.gov/downloads.html> (last accessed December 26, 2018).

North Carolina State Board of Elections. 2018. "voter_stats_ 20181106.zip.” December 5. URL: <https://dl.ncsbe.gov/ index.html?prefix=ENRS/2018_11_06/> (last accessed January 5, 2019).

Oklahoma State Election Board. 2018. "Election Results." URL: <https://www.ok.gov/elections/Election_Info/Election_ Results/index.html> (last accessed December 26, 2018).

Rozenas, Arturas. 2017. "Detecting Election Fraud from Irregularities in Vote-Share Distributions." Political Analysis 25(1): 41-56.

Udani, Adriano and David C. Kimball. 2018. "Immigrant Resentment and Voter Fraud Beliefs in the U.S. Electorate." American Politics Research 46(3): 402-433.

Wand, Jonathan N., Kenneth W. Shotts, Jasjeet S. Sekhon, Walter R. Mebane, Jr., Michael C. Herron, and Henry E. Brady. 2001. "The Butterfly Did It: The Aberrant Vote for Buchanan in Palm Beach County, Florida." American Political Science Review 95(4): 793-810.

Wilson, David C. and Paul R. Brewer. 2013. "The Foundations of Public Opinion on Voter ID Laws: Political Predispositions, Racial Resentment, and Information Effects." Public Opinion Quarterly 77(4): 962-984.

Address correspondence to:

Michael C. Herron

Dartmouth College 6108 Silsby Hall Hanover, NH 03755-3547

E-mail: michael.c.herron@dartmouth.edu

Received for publication January 8, 2019; received in revised form April 19, 2019; accepted April 26, 2019; published online August 21, 2019. 